IBAD Sosyal Bilimler Dergisi

IBAD Journal of Social Sciences

dergipark.org.tr/ibad

IBAD, 2021; (10): 96-126

DOI: $10.21733 /$ ibad. 852233

Özgün Araştırma / Original Article

\title{
Türkçe Ders Kitaplarındaki Yazma Etkinliklerinin İncelenmesi
}

\section{Examination of Writing Activities in Turkish Textbooks}

\author{
Mehmet Önder Karacaoğlu ${ }^{1^{*}}$ \\ Murat Dağ 2 \\ Oğuzhan Uzun ${ }^{3}$

\section{* Sorumlu yazar \\ Corresponding author}

${ }^{1}$ Türkçe öğretmeni, Millî Eğitim Bakanlığı, Türkiye Turkish teacher, Ministry of National Education, Turkey mehmetonder25@gmail.com

ORCID ID 0000-0002-4461-6021

2Türkçe öğretmeni, Millî Eğitim Bakanlığı, Türkiye Turkish teacher, Ministry of National Education, Turkey dag390@gmail.com

ORCID ID 0000-0001-6152-2425

${ }^{3}$ Türkçe Öğretmeni, Millî Eğitim Bakanlığı, Türkiye Turkish teacher, Ministry of National Education, Turkey oguzhan.uzunn1993@gmail.com

ORCID ID 0000-0003-4700-8360

Makale geliş tarihi / First received : 02.01.2020

Makale kabul tarihi / Accepted : 21.02.2021

Bilgilendirme / Acknowledgement:

Yazarlar aşağı daki billgilendirmeleri yapmaktadırlar:

1- Araştırmada yazarların katkı oranı eşittir.

2- Makalenin yazarları arasında çıkar çatışması bulunmamaktadır.

3- Makalemizde ders kitapları üzerinden inceleme yapıldığından etik kurulu izni ve/veya yasal/özel izin alınmasını gerektiren bir durum yoktur.

4- Bu makalede araştırma ve yayın etiğine uyulmuştur.

This article was checked by Turnitin. Similarity Index 36\%

\section{Atıf bilgisi / Citation:}

Karacaoğlu, M.Ö., Dağ, M., Uzun, O. (2021). Türkçe ders kitaplarındaki yazma etkinliklerinin incelenmesi. IBAD Sosyal Bilimler Dergisi, (10), 96-126. 
Millî Eğitim Bakanlığı, Türkçe derslerinde kullanılmak üzere Talim Terbiye Kurulu kararları doğrultusunda Türkçe ders kitaplarını belirlemektedir. Bu kitaplar gerek özel yayınevleri gerekse Millı̂ Eğitim Bakanlığının kendi bünyesinde oluşturduğu komisyonlar tarafından hazırlanmaktadır. 2003-2004 eğitim-öğretim yılından itibaren Bakanlık tarafından ücretsiz olarak öğrencilere ulaştırılan bu kitaplar Türkçe dersinin temel dil becerilerinin geliştirilmesi sürecine uygun olarak etkinlik temelli olarak hazırlanmaktadır. Türkçe Dersi Öğretim Programı'nda (MEB, 2019) Türkçe dersinde kullanılacak kitaplarda kaç tema yer alması gerektiği, yer alan metinlerin tür dağılımı, öğrenciler tarafından edinilmesi gereken kazanımlar yer almaktadır. Bu kazanımların alanları temel dil becerilerine göre belirlenmiştir. Bu çalışma, ortaokul ve imam-hatip ortaokullarında kullanılan Türkçe ders kitaplarında yer alan yazma becerisine yönelik hazırlanmış etkinliklerin Türkçe Dersi Öğretim Programı (MEB, 2019) ile ne kadar tutarlılık içinde olduğunu tespit etmeyi amaçlamaktadır. Çalışma analitik araştırma modeli ile tasarlanmıştır. Araştırmada inceleme nesnesi olarak 2020-2021 eğitimöğretim yılında her sınıf düzeyinde farklı yayınevlerince hazırlanan dört Türkçe ders kitabı incelenmiştir. Araştırma sonucunda temalarda yer alan yazma etkinlikleri; sayı, tür ve Türkçe Dersi Öğretim Programı'na (MEB, 2019) uygunluk açısından incelenmiştir. Etkinliklerin hangi kazanımla ilişkili olduğu ortaya konulmuştur. Sinıflar bazında tasnif edilerek tablolaştırılan yazma etkinliklerinin Türkçe Dersi Öğretim Programı'ndaki (MEB, 2019) yazma becerisi kazanımlarına uygunluğu değerlendirilmiştir. 8 . sınıf Türkçe ders kitabının nispeten yeterli düzeyde olduğu; 5, 6, 7. sınıf kitaplarının ise yazma becerisinin gelişimi için tam anlamıyla yeterli olmadığı sonucuna ulaşılmıştır.

\section{Anahtar kelimeler}

Türkçe ders kitabı, yazma becerisi, etkinlik, Türkçe

dersi öğretim programı (2019).
The Ministry of National Education determines Turkish textbooks to be used in Turkish lessons in line with the decisions of the Board of Education. These books are prepared by both private publishing houses and the commissions established by the Ministry of National Education. These books, which are delivered to students free of charge by the Ministry since the academic year of 2003-2004, are prepared on an activity-based basis in accordance with the process of developing the basic language skills of the Turkish course. The Turkish Lesson Curriculum (2019) includes how many themes should be included in the books to be used in the Turkish course, the type distribution of the texts, and the acquisitions that should be acquired by the students. The areas of these acquisitions are determined according to basic language skills. This study aims to determine how consistent the activities prepared for writing skills in Turkish textbooks used in middle schools and imam-hatip secondary schools are with the Turkish Lesson Curriculum (2019). The study was designed with an analytical research model. In the study, four Turkish textbooks prepared by different publishers at each grade level in the 2020-2021 academic year were analyzed as the object of investigation. Writing activities included in the themes as a result of the research; It has been examined in terms of number, type and compliance with the Turkish Course Curriculum (2019). It has been revealed that the activities are related to which achievement. The writing activities, which were classified and tabulated on the basis of classes, were evaluated in accordance with the writing skill acquisitions in the Turkish Course Curriculum (2019). The 8th grade Turkish textbook is relatively sufficient; It was concluded that 5 th, 6 th, and 7 th grade books are not fully sufficient for the development of writing skills.

\section{Keywords}

Turkish textbook, writing skill, activity, Turkish course curriculum (2019). 


\section{GİRIŞ}

Türkçe Dersi Öğretim Programı (MEB, 2019), dil becerilerinin geliştirilmesi ve bu becerilerin birey tarafından günlük yaşamda sağlıklı bir şekilde kullanılabilmesini hedeflemektedir. İlgili hedef diğer tüm alanlarda öğrenme, kişisel ve sosyal gelişim ile meslekî becerileri kazanmanın ön koşulu olarak kabul edilmektedir. Bu bağlamda ilgili programda geliştirilmesi hedeflenen dört temel dil becerisi yer almaktadır. Bu beceriler dinleme, konuşma, okuma ve yazmadır.

Dört temel dil becerisiyle birlikte Türkçe Dersi Öğretim Programı'nda (MEB, 2006) dil bilgisi öğrenme alanına ayrı bir başlık açılmıştır. Türkçe Dersi Öğretim Programı'nda (MEB, 2019) ise bu şekilde bir başlıklandırma yapılmadan dil bilgisi öğrenme alanının diğer dil becerilerini destekleyici unsur olarak öğrenme alanlarının içerisine yerleştirildiği görülmektedir.

Alanyazında dinleme ve okuma becerileri anlama becerisi olarak adlandırılırken konuşma ve yazma becerileri ise anlatma becerileri olarak adlandırılmaktadır. Anlama, okunan metnin veya dinlenen bir konuşmanın içerik açısından doğru algılanmasıdır (Aktaş ve Gündüz, 2004, s. 57). Anlatma ise algılanan içeriğin söz veya yazı ile aktarılmasıdır. Bu açıdan anlatma becerisi dışa dönük bir beceri olarak tanımlanabilir.

Yazma becerisine yönelik olarak alanyazında birçok tanım bulunmaktadır. Göçer (2014) yaptığ1 tanımda yazmayı bireyin duygularını, düşüncelerini, hayal ettiklerini, tasarladıkların kaleme alması, kâ̆ğıda aktarması olarak belirtmektedir. Bu noktada yazmanın bir üretim becerisi olduğu ve bu yönünün ön planda tutulması gerektiği anlaşılmaktadır. Yazma ile ilgili yapılan bir diğer tanımda (Yangın, 2002) ise becerinin iletişimsel yönü olduğu ve insanlar arasında iletişimin temel unsurlarından biri olduğu belirtilmektedir. Söz konusu iki tanım yazmanın üretimsel ve iletişimsel yönünü ortaya koyarken Özdemir (1991) tarafından yapılan tanımda ise yazmanın bir plan dâhilinde oluşan düşünsel etkinlikler olduğu dile getirilmektedir. Konu seçimi, amaç belirlenmesi, düşüncelerin gözden geçirilmesi söz konusu plan dâhilinde yapılması gereken etkinlikler olarak belirtilmektedir.

Türkçe Dersi Öğretim Programı'nda (MEB, 2019) yazma etkinlikleri tematik yaklaşımla ele alınarak metin içi, metin dışı ve metinler arası etkinlikler yoluyla oluşturulacak şekilde planlanmıştır. Öğrenci gelişim düzeyi de göz önünde bulundurularak 1. sınıftan 8. sınıfa kadar ilgili beceri kazanımları bir aşamalılık dâhilinde programa eklenmiştir. Türkçe Dersi Öğretim Programı'nda (MEB, 2019) ortaokul seviyesinde yazma becerisi ile ilgili 5. sinıfta 16 kazanım bulunmaktadır. 6 . sınıf seviyesinde yazma becerisi ile ilgili kazanım sayısı ise 14 tür. Bununla birlikte 7. sınıf seviyesinde yazma becerisi ile ilgili kazanımlara bakıldığında 17 kazanımın yer aldığı görülmektedir. 8. sınıf seviyesinde ise yazma becerisi ile ilgili 20 kazanım bulunmaktadır.

İlgili 20 kazanımdan 13 tanesi tüm sınıf seviyelerinde ortak olarak yer almaktadır. Bununla birlikte ortak kazanımların açılamalarında sınıf seviyelerine göre farklllıklar görülebilmektedir. Örneğin, 5. sınıf seviyesinde yer alan "T.5.4.4. Yazma stratejilerini uygular" kazanımının açılamasında "Güdümlü, metin tamamlama, bir metni kendi kelimeleri ile yeniden oluşturma, boşluk doldurma" gibi yöntem ve tekniklerin kullanılması önerilirken 8. sinıf seviyesinde yer alan "T.8.4.4. Yazma stratejilerini uygular" kazanımının açıklamasında ise "Not alma, özet çıkarma, eleştirel, yaratıcl, serbest, kelime ve kavram havuzundan seçerek yazma, bir metinden ve duyulardan hareketle yazma" gibi yöntem ve tekniklerin kullanılması önerilmiştir. Bu noktada öğrencilerin sinıf seviyesinin göz önünde bulundurulduğu görülmektedir. 
Daha önceki Türkçe Öğretim Programı'nda (MEB, 2006) yazma becerisi ile ilgili olarak kullanılan yöntem ve teknikler şunlardır: "Not alma, özet çıkarma, boşluk doldurma, kelime ve kavram havuzundan seçerek yazma, serbest yazma, kontrollü yazma, güdümlü yazma, yaratıcl yazma, metin tamamlama, tahminde bulunma, bir metni kendi kelimeleriyle yeniden oluşturma, bir metinden hareketle yeni bir metin oluşturma, duyulardan hareketle yazma, grup olarak yazma, eleştirel yazma". 2019'da yayımlanan ve hâlihazırda kullanımda olan Türkçe Dersi Öğretim Programı'nda (MEB, 2019) ise yazma becerisine yönelik olarak kullanılan yöntem ve teknikler ayrı bir açıklama hâlinde verilmemektedir.

Türkçe Dersi Öğretim Programı'ndan (MEB, 2006) farklı olarak yöntem ve teknikler, Türkçe Dersi Öğretim Programı́nda (MEB, 2019) strateji başlı̆̆ı altında kazanım olarak verilmektedir. Türkçe Sözlük'te strateji, "izlem, önceden belirlenen bir amaca ulaşmak için tutulan yol" (Türkçe Sözlük, 2011, s. 1240) olarak tanımlanmaktadır. Tanımda yer aldığı gibi ilgili programda strateji, beceriler açısından belirlenen hedeflere ulaşmak için kullanılan yöntem ve teknikleri kapsayıcı bir kavram olarak karşımıza çıkmaktadır. Bu bağlamda ders kitabı aracılığıyla etkinlikler gerçekleştirilirken ilgili stratejiler kullanılır. Sekizinci sınıflara ait "T.8.4.4. Yazma stratejilerini uygular." kazanımının açıklamasında" Not alma, özet çıkarma, eleştirel, yaratıcı, serbest, kelime ve kavram havuzundan seçerek yazma, bir metinden ve duyulardan hareketle yazma gibi yöntem ve tekniklerin kullanılması sağlanır." yer verilen stratejiler bu duruma örnektir.

Söz konusu stratejilerin öğrencilere kazandırılması noktasında etkinlikler oldukça önemlidir. Türkçenin ana dili olarak öğretiminde kullanılan etkinliklerden bir kısmı şu şekilde sıralanabilir (Sever, 2004, s. 26): "paragraf oluşturma, yazma planı hazırlama, özetleme, öykü yazma, mektup yazma, dilekçe yazma, görselden hareketle yazma, gezi yazısı, betimleme yazıları, not alma, anı yazma, deneme yazma, metin tamamlama, başlık yazma". İlgili etkinlikler yazma becerisini doğrudan geliştirmeye yöneliktir. Bu nedenle ders kitabında yer alan metin altı etkinlikleri, yazma becerisinin geliştirilmesi açısından oldukça önemli bir kaynaktır.

Yazma becerisini geliştirmek için etkinliklerin bu derece önemli olduğu bir ortamda ilgili etkinliklerin gerçekleştirilmesi ve yazma becerisinin geliştirilmesi için öğretmenlerin dikkat etmesi gereken birtakım ilkeler yer almaktadır (Göğüş, 1978; Demirel, 1999; Özbay, 2006; Göçer, 2014). Bunlardan bazıları şu şekilde sıralanmaktadır:

- Yazma eğitiminin temel ilkesi yazdırmaktır,

- Bireysel farklılıklar göz önünde bulundurulmalıdır,

- Çalışmalarda öğrenciler merkeze alınmalıdır,

- Çalışmalar günlük yaşamla ilişkilendirilmelidir,

- Dil bilgisi çalışmaları uygulama ve teorik açıdan yazma etkinlikleri içerisinde yer almalidir,

- Yazma etkinlikleri ve konuşma etkinlikleri arasında ilişki kurulmalıdır,

- Öğretmenler de öğrencileriyle birlikte yazmalıdır,

- Öğrenci yazma konusuna ilgi duymalıdır,

- Öğrenciye sorumluluk duygusu kazandırılmalıdır,

- Öğrencilerin yazma çalışmaları arşivlenmelidir.

Etkinliklerin yer aldığı, birinci kaynak olarak kullanılan Türkçe ders kitaplarının yazma becerisi açısından ayrıca incelenmesi gerekmektedir. Ders kitabı "belli ölçülere göre incelendikten sonra belli bir okul, sınıf ve ders için öğretmen ve öğrencilere temel kaynak olarak gönderilen kitaptır (Oğuzkan, 
1993, s. 83). İlgili temel kaynağın o dersin öğretim programı ile ilişkili olması ve programda yer alan kazanımları yansıtabilmesi, dikkat edilmesi gereken hususların başında gelmektedir. Demirel ve Kıroğlu (2005) tarafından yapılan tanımda ders kitabının eğitim programında yer alan hedef, içerik, öğrenme ve öğretme süreçleriyle ölçme ve değerlendirme boyutlarına uygun olarak hazırlanmış olması gerektiği belirtilmektedir. Çerçi (2016) 6. sınıf Türkçe ders kitabındaki etkinlikleri incelediği çalışmasında ilgili etkinliklerin "anlama ve anlatma becerilerine dayanması, öğrencinin etkin katılımının sağlanması, gerçek hayatla ilişkilendirilebilmesi, öğrenci ve öğretmen arasında iletişimsel süreci gerektiren eğitici çalışmalardan oluşması" gerektiğini bildirmektedir.

Alanyazında Türkçe ders kitaplarında yer alan etkinliklerin yetersizliğini tespit eden çalışmalar yer almaktadır. (İşcan, 2004; Yılmaz, 2005; Duran, 2006; Kayabekir, 2010; Ayhan, 2010; Batur, 2010; Kırbaş, Orhan ve Topal, 2012; Akın, 2015; Mazlum ve Mazlum, 2016; İşcan ve Cımbız, 2018). Bu açıdan bakıldığında dil becerilerinin öğrencilere kazandırılması için kullanılan temel kaynak olan ders kitaplarının incelenmesi ve gerekli düzenlemelerin gerçekleştirilmesi oldukça önemlidir.

Buradan hareketle, ilgili araştırmanın amacı ortaokul ve imam-hatip ortaokullarında kullanılan Türkçe ders kitaplarında yer alan yazma becerisine yönelik hazırlanan etkinliklerin Türkçe Dersi Öğretim Programı (MEB, 2019) ile ne kadar tutarlılık içinde olduğunu tespit etmektir.

\section{YÖNTEM}

\subsection{Araştırmanın Modeli}

Ortaokul ve imam-hatip ortaokullarında kullanılan Türkçe ders kitaplarında yer alan yazma becerisine yönelik hazırlanmış etkinliklerin Türkçe Dersi Öğretim Programı (2019) ile ne kadar tutarlılık içinde olduğunu tespit etmeyi amaçlayan bu çalışma analitik araştırma modeli ile desenlenmiştir. Analitik araştırmalarda doküman incelemesi yöntemiyle olaylar, düşünceler, kavramlar ve eserler analiz edilir. Analitik araştırmalar nitel ve nicel araştırma yöntemlerinin özelliklerini içerir. Direkt iletişime geçilmeyen analitik araştırma modellerinde veri toplama ve analiz süreci genellikle dokümanlara dayalıdır (McMillan, 2004; McMillan ve Schumacher, 2014; Burkett, 1990'dan akt. Boyacı, Güner ve Babadağ, 2017, s. 177-178). Bu çalışmada da 2020-2021 eğitim-öğretim yılında kullanılan 5. Sınıf Türkçe Ders Kitabı (Anıttepe Yayıncılık), 6. Sınıf Türkçe Ders Kitabı (Ekoyay Eğitim Yayıncılık), 7. Sınıf Türkçe Ders Kitabı (Özgün Yayınları) ve 8. Sınıf Türkçe Ders Kitabı (Millı̂ Eğitim Bakanlığı) doküman olarak kabul edilmiş ve bunlardan elde edilen veriler içerik analizi yöntemiyle analiz edilmiştir.

\subsection{Amaç}

Araştırmamızın amacı ortaokul ve imam-hatip ortaokullarında kullanılan Türkçe ders kitaplarında yer alan yazma becerisine yönelik hazırlanan etkinliklerin Türkçe Dersi Öğretim Programı (MEB, 2019) ile ne kadar tutarlılık içinde olduğunu tespit etmektir. Bu bağlamda aşağıdaki sorulara cevap aranmıştır:

- 5, 6, 7 ve 8. sınıf Türkçe ders kitaplarında yer alan yazma etkinliklerinin sayısı kaçtır?

- 5, 6, 7 ve 8. sınıf Türkçe ders kitaplarında yer alan yazma etkinliklerinin türü nedir?

- 5, 6, 7 ve 8. sınıf Türkçe ders kitaplarında yer alan yazma etkinliklerinin ve Türkçe Dersi Öğretim Programı'ndaki (MEB, 2019) hangi kazanım(lar)la ilgilidir? 
- 5, 6, 7 ve 8 . sınıf Türkçe ders kitaplarında yazma becerisine yönelik hazırlanan etkinliklerin Türkçe Dersi Öğretim Programı (MEB, 2019) ile tutarlılık görünümü nasıldir?

\subsection{Verilerin Toplanması ve Analizi}

Araştırma kapsamında doküman incelemesi ile elde edilen bulgular tasnif edilmiştir. Doküman incelemesi genel olarak sözel alanda araştırma yapanların kullandığı bir yöntem olarak karşımıza çıkmaktadır. Durdu ve Özden'e göre (2016, s. 109) dokümanlar, doküman inceleme, doküman analizi, arşiv kayıtları gibi farklı terimlerle adlandırılsa da dokümanlar yazılı, görsel ve fiziksel her türlü materyali içerir.

Araştırmada Türkiye'nin birçok ilinde 2020-2021 yılında okutulan Türkçe ders kitapları temel alınmıştır. Bu kitaplardan elde edilen veriler içerik analizi yoluyla analiz edilmiştir. Yıldırım ve Şimşek'e göre (2011); betimsel analiz önceden belirlenmiş bir kalıba bağlı olarak nitel verilerin işlenmesi, bulguların tanımlanması ve tanımlanan bulguların yorumlanması basamaklarını içeren analiz yaklaşımıdır. İçerik analizi, betimsel analizde fark edilmeyen kavram ve temaların keşfedilmesini sağlayan bir analizdir. İçerik analizinde temelde yapılan işlem, birbirine benzeyen verileri belirli kavramlar ve temalar çerçevesinde bir araya getirerek bunları raporlamaktır (Yıldırım ve Şimşek, 2011, s. 242). Araştırmanın analiz sürecince öncelikle araştırmanın amacına uygun olarak ortaokul ve imam-hatip ortaokulu Türkçe ders kitaplarında yer alan yazma etkinlikleri derlenmiştir. Bu kitaplarda yer alan yazma etkinliklerinin sayısı, türü ve Türkçe Dersi Öğretim Programı́nda (MEB, 2019) yer alan hangi kazanımla ilişkili olduğu ortaya konulmuştur. Sınıflar bazında tasnif edilerek tablolaştırılan yazma etkinliklerinin Türkçe Dersi Öğretim Programı'ndaki (MEB, 2019) yazma becerisi kazanımlarına uygunluğu değerlendirilmiştir. Ayrıca temalar içerisinde yazma etkinliği yer almayan metin olup olmadığı da belirtilmiştir. Son aşamada elde edilen bulgular yorumlanarak raporlandırılmıştır.

Başkale'ye göre (2016) nitel araştırmalarda araştırmanın birçok yönünün incelenmesi için bağımsız bir araştırmacının araştırmaya dâhil edilme süreci, araştırmanın inandırıcıllğının sağlanması adına önemlidir. Bu kapsamda araştırmacılar, analiz raporlarını bağımsız bir araştırmacıya göndererek kontrol edilmesini sağlamıştır. Bunun yanında, inandırıcılığın artması için bu araştırmada doküman, üç farklı araştırmacı tarafından bağımsız olarak analiz edilmiş ve analizler karşılaştırılmıştır. Tüm araştırmacıların gerçekleştirdikleri analizler çerçevesinde elde edilen verilerin sınıflandırılmasında ve hangi kazanımları karşıladı̆̆ının belirlenmesinde görüş birliğine varana kadar tartışmalar yapılmış ve analizlere son hâli verilmiştir. Araştırmacılar verilerinin sunulması sırasında elde edilen sonuçları herhangi bir yorum yapmadan doğrudan sunarak ayrıntılı bir şekilde betimlemişlerdir.

\section{BULGULAR}

Ortaokul ve imam-hatip ortaokulu Türkçe ders kitaplarında yer alan yazma etkinlikleri incelenmiştir. Bu kitaplarda yer alan yazma etkinliklerinin sayısı, türü ve Türkçe Dersi Öğretim Programı'nda (MEB, 2019) yer alan hangi kazanımla ilişkili olduğu ortaya konulmuştur. Sınıflar bazında tasnif edilerek tablolaştırılan yazma etkinliklerinin Türkçe Dersi Öğretim Programı'ndaki (MEB, 2019) yazma becerisi kazanımlarına uygunluğu değerlendirilmiştir. Ayrıca temalar içerisinde yazma etkinliği yer almayan metin olup olmadığı da belirtilmiştir.

\subsection{Sınıf Türkçe Ders Kitabı Yazma Etkinliklerinin İncelenmesi}


Anıttepe Yayıncılık tarafından hazırlanan "Ortaokul ve Imam Hatip Ortaokulu Türkçe 5. Sınıf" ders kitabında yer alan yazma etkinlikleri incelenmiştir. İnceleme sonucunda temalarda ne tür yazma etkinlikleri olduğu, bu etkinliklerin Türkçe dersi öğretim programında yer alan hangi kazanımla ilişkili olduğu tablolaştırılmıştır.

Tablo 1. 5. Sınıf Türkçe Ders Kitabı 1. Temada Yer Alan Yazma Etkinlikleri

\begin{tabular}{|c|c|c|c|}
\hline \multicolumn{4}{|c|}{ 1. TEMA: BİREY VE TOPLUM } \\
\hline Metin & $\begin{array}{l}\text { Etkinlik } \\
\text { Numarası }\end{array}$ & Etkinlik & İlgili Kazanım/Kazanımlar \\
\hline Memleket İsterim & 11. Etkinlik & Olay yazısı yazma & $\begin{array}{l}\text { T.5.4.3. Hikâye edici metin yazar } \\
\text { T.5.4.6. Bir işin işlem basamaklarını } \\
\text { yazar } \\
\text { T.5.4.15. Yazdıklarının içeriğine } \\
\text { uygun başlık belirler }\end{array}$ \\
\hline $\begin{array}{l}\text { Hoşça Kalın, } \\
\text { Güle Güle }\end{array}$ & 9. Etkinlik & $\begin{array}{l}\text { Verilen sözleri } \\
\text { kullanarak metin } \\
\text { yazma }\end{array}$ & $\begin{array}{l}\text { T.5.4.4. Yazma stratejilerini uygular. } \\
\text { T.5.4.6. Bir işin işlem basamaklarını } \\
\text { yazar } \\
\text { T.5.4.15. Yazdıklarının içeriğine } \\
\text { uygun başlık belirler }\end{array}$ \\
\hline $\begin{array}{l}\text { Anadolu'da } \\
\text { Konukseverlik } \\
\text { Gelenekseldir }\end{array}$ & 7. Etkinlik & Şiir tamamlama & $\begin{array}{l}\text { T.5.4.1.Şiir yazar } \\
\text { T.5.4.4. Yazma stratejilerini uygular }\end{array}$ \\
\hline $\begin{array}{l}\text { İlk Ders } \\
\text { (Dinleme/İzleme } \\
\text { Metni) }\end{array}$ & 12. Etkinlik & $\begin{array}{l}\text { Bilgilendirici } \\
\text { metin yazma }\end{array}$ & $\begin{array}{l}\text { T.5.4.2. Bilgilendirici metin yazar } \\
\text { T.5.4.6. Bir işin işlem basamaklarını } \\
\text { yazar } \\
\text { T.5.4.15. Yazdıklarının içeriğine } \\
\text { uygun başlık belirler }\end{array}$ \\
\hline
\end{tabular}

Tablo 1'den anlaşıldı̆̆ gibi "Birey ve Toplum" adlı birinci temada dört farklı türde yazma etkinliği yer almaktadır. Bu etkinlikler dokuz farklı kazanımla ilişkilidir.

Tablo 2. 5. Sınıf Türkçe Ders Kitabı 2. Temada Yer Alan Yazma Etkinlikleri

\begin{tabular}{|c|c|c|c|}
\hline \multicolumn{4}{|c|}{ 2. TEMA: MİLLÎ MÜCEDELE VE ATATÜRK } \\
\hline Metin & $\begin{array}{l}\text { Etkinlik } \\
\text { Numarası }\end{array}$ & Etkinlik & İlgili Kazanım/Kazanımlar \\
\hline $\begin{array}{l}\text { Mustafa Kemal'in } \\
\text { Kağnısı }\end{array}$ & 11. Etkinlik & $\begin{array}{l}\text { Şiiri } \\
\text { hikâyeleştirme }\end{array}$ & $\begin{array}{l}\text { T.5.4.3. Hikâye edici metin yazar } \\
\text { T.5.4.15. Yazdıklarının içeriğine } \\
\text { uygun başlık belirler }\end{array}$ \\
\hline $\begin{array}{l}\text { Dumlupınar } \\
\text { Savaşı }\end{array}$ & 10. Etkinlik & Mektup yazma & T.5.4.4. Yazma stratejilerini uygular \\
\hline $\begin{array}{l}6 \quad \text { Mart } 1915 \\
\text { Gecesi }\end{array}$ & 13. Etkinlik & Afiş hazırlama & $\begin{array}{l}\text { T.5.4.14. Kisa metinler yazar } \\
\text { T.5.4.4. Yazma stratejilerini uygular. }\end{array}$ \\
\hline $\begin{array}{l}15 \quad \text { Temmuz } \\
\text { Gecesi } \\
\text { (Dinleme/İzleme } \\
\text { Metni) }\end{array}$ & 8. Etkinlik & Slogan hazırlama & T.5.4.14. Kısa metinler yazar \\
\hline
\end{tabular}


Tablo 2'den anlaşıldığı gibi "Millî Mücadele ve Atatürk" adlı ikinci temada dört farklı türde yazma etkinliği yer almaktadır. Bu etkinlikler altı farklı kazanımla ilişkilidir.

Tablo 3. 5. Sınıf Türkçe Ders Kitabı 3.Temada Yer Alan Yazma Etkinlikleri

\begin{tabular}{|c|c|c|c|}
\hline \multicolumn{4}{|c|}{ 3. TEMA: DOĞA VE EVREN } \\
\hline Metin & $\begin{array}{l}\text { Etkinlik } \\
\text { Numarası }\end{array}$ & Etkinlik & İlgili Kazanım/Kazanımlar \\
\hline Bu Nehir Bizim & 12. Etkinlik & Hikâye yazma & $\begin{array}{l}\text { T.5.4.3. Hikâye edici metin yazar } \\
\text { T.5.4.9. Yazdıklarını düzenler } \\
\text { T.5.4.13. Formları yönergelerine } \\
\text { uygun doldurur } \\
\text { T.5.4.15. Yazdıklarının içeriğine } \\
\text { uygun başlık belirler }\end{array}$ \\
\hline Okland Adası & 9. Etkinlik & Tanitma yazısı & $\begin{array}{l}\text { T.5.4.14. Kısa metinler yazar } \\
\text { T.5.4.6. Bir işin işlem basamaklarını } \\
\text { yazar } \\
\text { T.5.4.15. Yazdıklarının içeriğine } \\
\text { uygun başlık belirler }\end{array}$ \\
\hline Deprem & 11. Etkinlik & $\begin{array}{l}\text { Hikâye } \\
\text { tamamlama }\end{array}$ & T.5.4.3. Hikâye edici metin yazar \\
\hline $\begin{array}{l}\text { Sakın Kesme } \\
\text { (Dinleme/İzleme } \\
\text { Metni) }\end{array}$ & $\begin{array}{l}\text { 5. Etkinlik } \\
\text { 12. Etkinlik }\end{array}$ & $\begin{array}{l}\text { Paragraf yazma } \\
\text { Dinlenen şiirden } \\
\text { hareketle yazma }\end{array}$ & $\begin{array}{l}\text { T.5.4.14. Kisa metinler yazar } \\
\text { T.5.4.4. Yazma stratejilerini uygular. }\end{array}$ \\
\hline
\end{tabular}

Tablo 3'ten anlaşıldığı gibi “Doğa ve Evren” adlı üçüncü temada dört farklı türde yazma etkinliği yer almaktadır. Bu etkinlikler sekiz farklı kazanımla ilişkilidir.

Tablo 4. 5. Sınıf Türkçe Ders Kitabı 4.Temada Yer Alan Yazma Etkinlikleri

\begin{tabular}{|c|c|c|c|}
\hline \multicolumn{4}{|c|}{ 4. TEMA: MİLLÎ KÜLTÜRÜMÜZ } \\
\hline Metin & $\begin{array}{l}\text { Etkinlik } \\
\text { Numarası }\end{array}$ & Etkinlik & İlgili Kazanım/Kazanımlar \\
\hline Kilim & 10. Etkinlik & $\begin{array}{l}\text { Bilgilendirici } \\
\text { metin yazma }\end{array}$ & T.5.4.2. Bilgilendirici metin yazar \\
\hline $\begin{array}{l}\text { Vatan } \quad \text { yahut } \\
\text { Silistre }\end{array}$ & 9. Etkinlik & $\begin{array}{l}\text { Görsel } \\
\text { çağrışımdan } \\
\text { hareketle } \\
\text { yazma }\end{array}$ & T.5.4.1.Şiir yazar \\
\hline Boğaç Han & 8. Etkinlik & $\begin{array}{l}\text { Hikâye } \\
\text { kurgulama }\end{array}$ & T.5.4.3. Hikâye edici metin yazar \\
\hline $\begin{array}{l}\text { Ali Kuşçu } \\
\text { (Dinleme/İzleme } \\
\text { Metni) }\end{array}$ & 9. Etkinlik & $\begin{array}{l}\text { Elektronik posta } \\
\text { yazma }\end{array}$ & T.5.4.14. Kisa metinler yazar \\
\hline
\end{tabular}

Tablo 4'ten anlaşıldığı gibi "Millî Kültürümüz" adlı dördüncü temada dört farklı türde yazma etkinliği yer almaktadır. Bu etkinlikler dört farklı kazanımla ilişkilidir.

Tablo 5. 5. Sınıf Türkçe Ders Kitabı 5.Temada Yer Alan Yazma Etkinlikleri 


\begin{tabular}{|c|c|c|c|}
\hline \multicolumn{4}{|c|}{ 5. TEMA: VATANDAŞLIK } \\
\hline Metin & $\begin{array}{l}\text { Etkinlik } \\
\text { Numarası }\end{array}$ & Etkinlik & İlgili Kazanım/Kazanımlar \\
\hline $\begin{array}{l}\text { Çocuk } \\
\text { Bahçesindeki } \\
\text { Bekçi }\end{array}$ & 10. Etkinlik & $\begin{array}{l}\text { Özdeyişten } \\
\text { hareketle } \\
\text { bilgilendirici } \\
\text { metin yazma }\end{array}$ & $\begin{array}{l}\text { T.5.4.2. Bilgilendirici metin yazar } \\
\text { T.5.4.4. Yazma stratejilerini uygular }\end{array}$ \\
\hline Bilinçli Tüketici & 9. Etkinlik & Dilekçe yazma & $\begin{array}{l}\text { T.5.4.14. Kisa metinler yazar } \\
\text { T.5.4.7. Yazılarını zenginleştirmek } \\
\text { için atasözleri, deyimler ve } \\
\text { özdeyişler kullanır }\end{array}$ \\
\hline Özgürlük & 10. Etkinlik & $\begin{array}{l}\text { Araştırmaya } \\
\text { dayalı şiir yazma }\end{array}$ & T.5.4.1.Şiir yazar \\
\hline $\begin{array}{l}\text { Sokak } \\
\text { (Dinleme/İzleme } \\
\text { Metni) }\end{array}$ & 9. Etkinlik & $\begin{array}{l}\text { Bilgilendirici } \\
\text { metin yazma }\end{array}$ & T.5.4.2. Bilgilendirici metin yazar \\
\hline
\end{tabular}

Tablo 5'ten anlaşıldığı gibi "Vatandaşlık" adlı beşinci temada dört farklı türde yazma etkinliği yer almaktadır. Bu etkinlikler altı farklı kazanımla ilişkilidir.

Tablo 6. 5. Sınıf Türkçe Ders Kitabı 6.Temada Yer Alan Yazma Etkinlikleri

\begin{tabular}{|c|c|c|c|}
\hline \multicolumn{4}{|c|}{ 6. TEMA: SAĞLIK VE SPOR } \\
\hline Metin & $\begin{array}{l}\text { Etkinlik } \\
\text { Numarası }\end{array}$ & Etkinlik & İlgili Kazanım/Kazanımlar \\
\hline $\begin{array}{l}\text { Karagöz Kibarlık } \\
\text { Öğreniyor }\end{array}$ & 11. Etkinlik & $\begin{array}{l}\text { Fikra (nükte) } \\
\text { tamamlama }\end{array}$ & $\begin{array}{l}\text { T.5.4.4. Yazma stratejilerini uygular } \\
\text { T.5.4.10. Yazdıklarını paylaşır }\end{array}$ \\
\hline Çitlembik & 9. Etkinlik & $\begin{array}{l}\text { Bilgilendirici } \\
\text { metin yazma }\end{array}$ & $\begin{array}{l}\text { T.5.4.2. Bilgilendirici metin yazar } \\
\text { T.5.4.15. Yazdıklarının içeriğine } \\
\text { uygun başlık belirler } \\
\text { T.5.4.9. Yazdıklarını düzenler }\end{array}$ \\
\hline Spor ve Beden & 9. Etkinlik & $\begin{array}{l}\text { Taslak oluşturup } \\
\text { planlı yazma }\end{array}$ & $\begin{array}{l}\text { T.5.4.4. Yazma stratejilerini uygular } \\
\text { T.5.4.15. Yazdıklarının içeriğine } \\
\text { uygun başlık belirler } \\
\text { T.5.4.9. Yazdıklarını düzenler } \\
\text { T.5.4.10. Yazdıklarını paylaşır }\end{array}$ \\
\hline $\begin{array}{l}\text { Tavşan ile } \\
\text { Kaplumbağa } \\
\text { (Dinleme/İzleme } \\
\text { Metni) }\end{array}$ & 12. Etkinlik & Fabl yazma & $\begin{array}{l}\text { T.5.4.3. Hikâye edici metin yazar } \\
\text { T.5.4.7. Yazılarını zenginleştirmek } \\
\text { için atasözleri, deyimler ve } \\
\text { özdeyişler kullanır } \\
\text { T.5.4.9. Yazdıklarını düzenler }\end{array}$ \\
\hline
\end{tabular}

Tablo 6'dan anlaşıldığı gibi "Sağ lık ve Spor" adlı altıncı temada dört farklı türde yazma etkinliği yer almaktadır. Bu etkinlikler on iki farklı kazanımla ilişkilidir. Yazma becerisinin geliştirilmesine yönelik en fazla kazanım bu temada yer almaktadır.

Tablo 7.5. Sınıf Türkçe Ders Kitabı 7.Temada Yer Alan Yazma Etkinlikleri 


\begin{tabular}{|c|c|c|c|}
\hline \multicolumn{4}{|c|}{ 7. TEMA: ERDEMLER } \\
\hline Metin & $\begin{array}{l}\text { Etkinlik } \\
\text { Numarası }\end{array}$ & Etkinlik & İlgili Kazanım/Kazanımlar \\
\hline $\begin{array}{l}\text { İyiliğin Değerini } \\
\text { Bilen Kim }\end{array}$ & - & - & - \\
\hline Büyüklere Saygı & 11. Etkinlik & Şiir yazma & T.5.4.1.Şiir yazar \\
\hline Yaşama Sevinci & 11. Etkinlik & $\begin{array}{l}\text { Hikâye } \\
\text { tamamlama } \\
\text { (düğüm bölümü) }\end{array}$ & $\begin{array}{l}\text { T.5.4.4. Yazma stratejilerini uygular } \\
\text { T.5.4.15. Yazdıklarının içeriğine } \\
\text { uygun başlık belirler }\end{array}$ \\
\hline $\begin{array}{l}\text { Paylaşalım } \\
\text { (Dinleme/İzleme } \\
\text { Metni) }\end{array}$ & 9. Etkinlik & $\begin{array}{l}\text { Düşüncelerini } \\
\text { yazma }\end{array}$ & $\begin{array}{l}\text { T.5.4.4. Yazma stratejilerini uygular } \\
\text { T.5.4.15. Yazdıklarının içeriğine } \\
\text { uygun başlık belirler } \\
\text { T.5.4.7. Yazılarını zenginleştirmek } \\
\text { için atasözleri, deyimler ve } \\
\text { özdeyişler kullanır }\end{array}$ \\
\hline
\end{tabular}

Tablo 7'den anlaşıldığı gibi "Erdemler" adlı yedinci temada üç farklı türde yazma etkinliği yer almaktadır. "İiliğ̈in Değerini Bilen Kim" adlı metnin etkinlikleri arasında yazma etkinliği bulunmamaktadır. Diğer metinlerde yer yazma etkinlikleri altı farklı kazanımla ilişkilidir.

Tablo 8. 5. Sınıf Türkçe Ders Kitabı 8.Temada Yer Alan Yazma Etkinlikleri

\begin{tabular}{|c|c|c|c|}
\hline \multicolumn{4}{|c|}{ 8. TEMA: BİLIMM VE TEKNOLOJİ } \\
\hline Metin & $\begin{array}{l}\text { Etkinlik } \\
\text { Numarası }\end{array}$ & Etkinlik & İlgili Kazanım/Kazanımlar \\
\hline Barkod & 9. Etkinlik & $\begin{array}{l}\text { Soruya } \\
\text { yazma }\end{array}$ & T.5.4.4. Yazma stratejilerini uygular \\
\hline $\begin{array}{l}\text { Sosyal Medya } \\
\text { Psikolojimizi } \\
\text { Bozdu }\end{array}$ & 11. Etkinlik & Afiş hazırlama & T.5.4.14. Kisa metinler yazar \\
\hline $\begin{array}{l}\text { Akıllı Ulaşım } \\
\text { Sistemleri }\end{array}$ & 8. Etkinlik & $\begin{array}{l}\text { Düşüncelerini } \\
\text { yazma }\end{array}$ & T.5.4.14. Kisa metinler yazar \\
\hline $\begin{array}{lr}\text { Aziz } & \text { Sancar } \\
\text { (Dinleme } & \text { İzleme } \\
\text { Metni) } & \end{array}$ & 8. Etkinlik & $\begin{array}{l}\text { Edinilen bilgiler } \\
\text { 1şı̆̆ında duygu ve } \\
\text { düşüncelerini } \\
\text { yazma }\end{array}$ & $\begin{array}{l}\text { T.5.4.4. Yazma stratejilerini uygular } \\
\text { T.5.4.15. Yazdıklarının içeriğine } \\
\text { uygun başlık belirler }\end{array}$ \\
\hline
\end{tabular}

Tablo 8'den anlaşıldığı gibi "Bilim ve Teknoloji" adlı sekizinci temada dört farklı türde yazma etkinliği yer almaktadır. Bu etkinlikler üç farklı kazanımla ilişkilidir.

5. sınıf ders kitabındaki yazma becerisine yönelik etkinlikler incelendiğinde Türkçe Dersi Öğretim Programı'nda (MEB, 2019) yer alan 16 yazma becerisi kazanımından 11 tanesinin yönerge ve yönlendirmelerde de anlaşılacak şekilde etkinliklerde yer aldığ1 tespit edilmiştir. Yazma etkinlikleri içerisinde "T.5.4.5. Büyük harfleri ve noktalama işaretlerini uygun yerlerde kullanır, T.5.4.8. Sayıları doğru yazar, T.5.4.11. Yazılarında ses olaylarına uğrayan kelimeleri doğru kullanır, T.5.4.12. Yazdıklarında yabancı dillerden alınmış, dilimize henüz yerleşmemiş kelimelerin Türkçelerini kullanır, T.5.4.16. Yazılarında uygun geçiş ve bağlantı ifadelerini kullanır" kazanımlarının belirgin bir şekilde yer almadığı dikkat çekmektedir. Buna karşın "Sağ $l ı k$ ve Spor" temasında yer 
alan "Çitlembik" metninin 9. etkinliğinin sonunda "Bilgilendirici Metin Yazma Öz Değerlendirme Formu" içerisinde yazma etkinliğinde herhangi bir yönlendirme yapılmamış olmasına rağmen kullanılmayan tüm kazanımların uygulanıp uygulanmadığına dair öz değerlendirme yapılması istenmiştir. Bununla birlikte aynı temada yer alan "Tavşan ile Kaplumbă̆a" dinleme/izleme metninin 12. etkinliğinin sonunda da "Öyküleyici Metin Yazma Öz Değerlendirme Formu" yer almaktadır. Burada dikkat çeken husus başta yönerge olarak verilmeyen bir kazanımın öğrenci tarafından edinilip edinilmediğinin tespitinin beklenmesindeki tutarsızlıktır. Ayrıca 252 sayfadan oluşan kitapta sadece iki kez öz değerlendirme yapıldığı, bunun da aynı temada yer alan iki farklı türdeki etkinlikte bulunduğu tespit edilmiştir. Sekiz farklı temada 31 yazma etkinliği varken buna yönelik öz değerlendirmenin sadece iki kez ve aynı temada yapılmış olması bu kazanıma yönelik öz değerlendirme sürecini eksik bırakacaktır. Bununla birlikte öğretmen değerlendirme formu veya akran değerlendirme formunun olmayışı da çok büyük eksikliktir.

"Erdemler" temasında "Büyüklere Saygı" metnine ait 10. etkinlikte "Paragraftaki yazım yanlışlarını bulunuz." şeklinde verilen etkinlikle "T.5.4.5. Büyük harfleri ve noktalama işaretlerini uygun yerlerde kullanır, T.5.4.8. Sayıları doğru yazar, T.5.4.11. Yazılarında ses olaylarına uğrayan kelimeleri doğru kullanır." kazanımı verilmeye çalışılmıştır. Ancak bu etkinlik yazma becerisinin gelişim süreci için üç farklı kazanımın edinimine uygun bir çalışma olarak değerlendirilememiştir.

5. sınıf ders kitabındaki etkinlik yönergeleri incelendiğinde birçok etkinlikte birden fazla kazanımın yer aldığı, birden fazla becerinin kazandırılmaya çalışıldığı görülmüştür. Yazma becerisinin çok yönlü bir süreç olmasından hareketle bu şekilde bir uygulamanın yerinde olduğu değerlendirilmiştir. "Doğa ve Evren" temasının ilk metni olan "Bu Nehir Bizim" adlı metne ait 12. etkinlik a, b, c, yönergeleri ile üç aşamalı olarak verilmiştir. İlk önce bir vakıfla ilgili bilgilendirici kısa bir metin verilmiş, daha sonra öğrencilerden edindikleri bilgilerden hareketle hayalî bir kulüp kurduklarını düşünmeleri istenmiş ve bu durumu öyküleştirerek yazmaları beklenmiştir. Etkinliğin üçüncü aşamasında ise bir kulüp kayıt formu örneği verilerek "T.5.4.13. Formları yönergelerine uygun doldurur" kazanımına uygun bir şekilde doldurulması istenmiştir. $\mathrm{Bu}$ şekilde farklı kazanımları aşama aşama veren çalışmaların yazma becerisinin gelişiminde daha etkin bir rol oynayacağı değerlendirilmektedir. Üstelik bir etkinlik içerisinde dört farklı yazma kazanımı da net olarak ele alınmış durumdadır.

5. sınıf yazma kazanımları içerisinde dil bilgisine yönelik sadece "T.5.4.11. Yazılarında ses olaylarına uğrayan kelimeleri doğru kullanır." kazanımı yer almaktadır. "T.5.3.10. Kökleri ve ekleri ayırt eder, T.5.3.11. Yapım ekinin işlevlerini açıklar." kazanımları ise Okuma/Söz varlığı başlı̆̆1 altında ele alınmıştır. Dil bilgisine dayalı bu kazanımların dil becerilerinden ayrı ele alınmadığı belirlenmiştir. Ancak dil bilgisi, öğretim süreci olduğu için yapılan bu bilgilerin kazanımlar içerisinde uygulanma süreci dikkate alınmalıdır.

5. sınıf ders kitabında afiş hazırlamadan elektronik postaya, şiirden hikâyeye, bilgilendirici metinden tanıtım yazısına kadar birçok farklı türde yazma etkinliği yer almaktadır. Bu etkinlikler içerisinde "T.5.4.4. Yazma stratejilerini uygular" kazanımının en çok tekrar eden kazanım olduğu görülmektedir. 5. sınıf öğrencilerinde yazma stratejilerinin uygulanabilirliğinden ziyade "Güdümlü, metin tamamlama, bir metni kendi kelimeleri ile yeniden oluşturma, boşluk doldurma, grup olarak yazma gibi yöntem ve tekniklerin kullanılması sağlanır." şeklindeki kazanım açıklamasının öne çıkmış olduğu değerlendirilmektedir. Nitekim bu açıklama öğrencinin yazabileceği birçok türe yönelik bir gelişim sürecini içermektedir. Tür 
bağlamında bakıldığında ise düşüncelerini yazma, bilgilendirici metin yazma, planlı yazma, dilekçe yazma gibi bilgilendirici ağırlıklı türlerin öne çıtığı, öyküleyici metin ve şiir yazmanın ise daha az yer bulduğu görülmektedir. Yazma etkinlikleri içerisinde yer alan fabl yazma etkinliğinin bu yaş grubu öğrencilerin öyküleme ve şiir yazma becerilerine katkı sağlayacağı ve bu gibi etkinliklerin arttırılmasının da yerinde olacağı düşünülmektedir.

\subsection{Sınıf Türkçe Ders Kitabı Yazma Etkinliklerinin İncelenmesi}

Ekoyay Eğitim Yayıncılık tarafından hazırlanan "Ortaokul ve Imam Hatip Ortaokulu Türkçe 6. Sınıf" ders kitabında yer alan yazma etkinlikleri incelenmiştir. İnceleme sonucunda temalarda ne tür yazma etkinlikleri olduğu, bu etkinliklerin Türkçe dersi öğretim programında yer alan hangi kazanımla ilişkili olduğu tablolaştırılmıştır.

Tablo 9. 6. Sınıf Türkçe Ders Kitabı 1. Temada Yer Alan Yazma Etkinlikleri

\begin{tabular}{|c|c|c|c|}
\hline \multicolumn{4}{|c|}{ 1. TEMA: DOĞA VE EVREN } \\
\hline Metin & $\begin{array}{l}\text { Etkinlik } \\
\text { Numarası }\end{array}$ & Etkinlik & İlgili Kazanım/Kazanımlar \\
\hline Meşeler & 6. Etkinlik & $\begin{array}{l}\text { Metin } \\
\text { Tamamlama }\end{array}$ & T.6.4.4. Yazma stratejilerini uygular. \\
\hline $\begin{array}{l}\text { Tartışarak... } \\
\text { Gerçeğe Doğru }\end{array}$ & 7. Etkinlik & $\begin{array}{l}\text { Karışık Cümle ve } \\
\text { Paragrafları } \\
\text { Düzenleme }\end{array}$ & T.6.4.4. Yazma stratejilerini uygular. \\
\hline $\begin{array}{l}\text { Elveda Ağustos } \\
\text { Böceği }\end{array}$ & 7. Etkinlik & Mektup yazma & T.6.4.2. Bilgilendirici metin yazar. \\
\hline $\begin{array}{l}\text { Deniz Hasreti } \\
\text { (Dinleme/izleme } \\
\text { metni) }\end{array}$ & 6. Etkinlik & $\begin{array}{l}\text { Farklı türde metin } \\
\text { yazma }\end{array}$ & T.6.4.4. Yazma stratejilerini uygular. \\
\hline
\end{tabular}

Tablo 9'dan anlaşıldığı gibi "Doğa ve Evren" adlı birinci temada dört farklı türde yazma etkinliği yer almaktadır. Bu etkinlikler iki farklı kazanımla ilişkilidir.

Tablo 10. 6. Sınıf Türkçe Ders Kitabı 2. Temada Yer Alan Yazma Etkinlikleri

\begin{tabular}{|c|c|c|c|}
\hline \multicolumn{4}{|c|}{ 2. TEMA: MİLLÎ MÜCADELE VE ATATÜRK } \\
\hline Metin & $\begin{array}{l}\text { Etkinlik } \\
\text { Numarası }\end{array}$ & Etkinlik & İlgili Kazanım/Kazanımlar \\
\hline $\begin{array}{l}\text { Kuşların Çektiği } \\
\text { Kağnı }\end{array}$ & 7. Etkinlik & $\begin{array}{l}\text { Metin } \\
\text { Tamamlama }\end{array}$ & T.6.4.4. Yazma stratejilerini uygular. \\
\hline Çanakkale & 8. Etkinlik & El ilanı tasarlama & T.6.4.14. Kisa metinler yazar. \\
\hline Anadolu İmecesi & 8. Etkinlik & $\begin{array}{l}\text { Metinden } \\
\text { hareketle yeni bir } \\
\text { metin yazma }\end{array}$ & T.6.4.4. Yazma stratejilerini uygular. \\
\hline $\begin{array}{l}\text { Baba } \\
\text { (Dinleme/izleme } \\
\text { metni) }\end{array}$ & $\begin{array}{l}\text { 8. Etkinlik } \\
\text { 9. Etkinlik }\end{array}$ & $\begin{array}{l}\text { Bilgilendirici } \\
\text { metin yazma } \\
\text { (Taslak } \\
\text { oluşturma) } \\
\text { Bilgilendirici } \\
\text { metin yazma }\end{array}$ & T.6.4.2. Bilgilendirici metin yazar. \\
\hline
\end{tabular}




\section{(Düzenleme, düzeltme, paylaşma)}

Tablo 10'dan anlaşıldığı gibi "Millî Mücadele ve Atatürk" adlı ikinci temada dört farklı türde yazma etkinliği yer almaktadır. Bu etkinlikler üç farklı kazanımla ilişkilidir.

Tablo 11. 6. Sınıf Türkçe Ders Kitabı 3. Temada Yer Alan Yazma Etkinlikleri

\begin{tabular}{|c|c|c|c|}
\hline \multicolumn{4}{|c|}{ 3. TEMA: ÇOCUK DÜNYASI } \\
\hline Metin & $\begin{array}{l}\text { Etkinlik } \\
\text { Numaras1 }\end{array}$ & Etkinlik & İlgili Kazanım/Kazanımlar \\
\hline Uçurtma & 9. Etkinlik & Şiir yazma & T.6.4.1. Şiir yazar. \\
\hline Oyun & 9. Etkinlik & Oyun tanitımi & $\begin{array}{l}\text { T.6.4.6. Bir işi işlem basamaklarına } \\
\text { göre yazar. }\end{array}$ \\
\hline $\begin{array}{l}\text { Kanatlanın } \\
\text { Çocuklar }\end{array}$ & 8. Etkinlik & $\begin{array}{l}\text { Tahmin ederek } \\
\text { yazma }\end{array}$ & T.6.4.4. Yazma stratejilerini uygular. \\
\hline $\begin{array}{l}\text { Oyuncak } \\
\text { (Dinleme/izleme } \\
\text { metni) }\end{array}$ & 7. Etkinlik & $\begin{array}{l}\text { Karışık Cümle ve } \\
\text { Paragrafları } \\
\text { Düzenleme }\end{array}$ & T.6.4.4. Yazma stratejilerini uygular. \\
\hline
\end{tabular}

Tablo 11'den anlaşıldığı gibi “Çocuk Dünyası" adlı üçüncü temada dört farklı türde yazma etkinliği yer almaktadır. Bu etkinlikler üç farklı kazanımla ilişkilidir.

Tablo 12. 6. Sınıf Türkçe Ders Kitabı 4. Temada Yer Alan Yazma Etkinlikleri

\begin{tabular}{|c|c|c|c|}
\hline \multicolumn{4}{|c|}{ 4. TEMA: ERDEMLER } \\
\hline Metin & $\begin{array}{l}\text { Etkinlik } \\
\text { Numarası }\end{array}$ & Etkinlik & İlgili Kazanım/Kazanımlar \\
\hline Sevgiyle & 5. Etkinlik & $\begin{array}{l}\text { Hikâye edici } \\
\text { metin yazma }\end{array}$ & T.6.4.3. Hikâye edici metin yazar. \\
\hline Azim & 7. Etkinlik & E-posta yazma & T.6.4.2. Bilgilendirici metin yazar. \\
\hline İyilik Üzerine & $\begin{array}{l}\text { 7. Etkinlik } \\
\text { 8. Etkinlik } \\
\text { 9. Etkinlik }\end{array}$ & $\begin{array}{l}\text { Formu } \\
\text { yönergelere } \\
\text { uygun doldurma } \\
\text { Metin tamamlama } \\
\text { Duyuru metni } \\
\text { yazma }\end{array}$ & $\begin{array}{l}\text { T.6.4.13. Formları yönergelerine } \\
\text { uygun doldurur. } \\
\text { T.6.4.4. Yazma stratejilerini uygular. } \\
\text { T.6.4.4. Yazma stratejilerini uygular. }\end{array}$ \\
\hline $\begin{array}{l}\text { Ceylana Yardım } \\
\text { Edenler } \\
\text { (Dinleme/izleme } \\
\text { metni) }\end{array}$ & 10. Etkinlik & $\begin{array}{l}\text { Hikâye edici } \\
\text { metin yazma }\end{array}$ & T.6.4.3. Hikâye edici metin yazar. \\
\hline
\end{tabular}

Tablo 12'den anlaşıldığı gibi "Erdemler" adlı dördüncü temada altı farklı türde yazma etkinliği yer almaktadır. Bu etkinlikler dört farklı kazanımla ilişkilidir.

Tablo 13. 6. Sınıf Türkçe Ders Kitabı 5. Temada Yer Alan Yazma Etkinlikleri

\section{TEMA: MÍLLÎ KÜLTÜRÜMÜZ}




\begin{tabular}{|c|c|c|c|}
\hline Metin & $\begin{array}{l}\text { Etkinlik } \\
\text { Numarası }\end{array}$ & Etkinlik & İlgili Kazanım/Kazanımlar \\
\hline Gazlı Göl & 10. Etkinlik & $\begin{array}{l}\text { Hikâye edici } \\
\text { metin yazma }\end{array}$ & T.6.4.3. Hikâye edici metin yazar. \\
\hline Forsa & 10. Etkinlik & $\begin{array}{l}\text { Metin tamamlama } \\
\text { (sonuç bölümü) }\end{array}$ & T.6.4.4. Yazma stratejilerini uygular. \\
\hline Nineme Ninni & 8. Etkinlik & Şiir yazma & T.6.4.1. Şiir yazar. \\
\hline $\begin{array}{l}\text { Öğretmenimin } \\
\text { Mektubu } \\
\text { (Dinleme/izleme } \\
\text { metni) }\end{array}$ & 6. Etkinlik & Mektup yazma & T.6.4.2. Bilgilendirici metin yazar. \\
\hline
\end{tabular}

Tablo 13'den anlaşıldığ 1 gibi "Millî Kültürümüz" adlı beşinci temada dört farklı türde yazma etkinliği yer almaktadır. Bu etkinlikler dört farklı kazanımla ilişkilidir.

Tablo 14. 6. Sınıf Türkçe Ders Kitabı 6. Temada Yer Alan Yazma Etkinlikleri

\begin{tabular}{|c|c|c|c|}
\hline \multicolumn{4}{|c|}{ 6. TEMA: BİLIM VE TEKNOLOJİ } \\
\hline Metin & $\begin{array}{l}\text { Etkinlik } \\
\text { Numarası }\end{array}$ & Etkinlik & İlgili Kazanım/Kazanımlar \\
\hline Büyük Keşifler & $\begin{array}{l}\text { 5. Etkinlik } \\
\text { 6. Etkinlik }\end{array}$ & $\begin{array}{l}\text { Duyuru metni } \\
\text { yazma } \\
\text { Hikâye edici } \\
\text { metin yazma }\end{array}$ & T.6.4.3. Hikâye edici metin yazar. \\
\hline Mavi Portakal & 6. Etkinlik & Metin tamamlama & T.6.4.4. Yazma stratejilerini uygular. \\
\hline $\begin{array}{l}\text { Buldum... } \\
\text { Buldum... }\end{array}$ & 8. Etkinlik & $\begin{array}{l}\text { Verilen unsurları } \\
\text { kullanarak hikâye } \\
\text { yazma }\end{array}$ & T.6.4.3. Hikâye edici metin yazar. \\
\hline $\begin{array}{l}\text { İçimdeki Müzik } \\
\text { (Dinleme/izleme }\end{array}$ & 9. Etkinlik & $\begin{array}{l}\text { Bilgilendirici } \\
\text { metin yazma }\end{array}$ & T.6.4.2. Bilgilendirici metin yazar. \\
\hline metni) & 10. Etkinlik & $\begin{array}{l}\text { Kullanim } \\
\text { kilavuzu yazma }\end{array}$ & $\begin{array}{l}\text { T.6.4.6. Bir işi işlem basamaklarına } \\
\text { göre yazar. }\end{array}$ \\
\hline
\end{tabular}

Tablo 14'ten anlaşıldığı gibi “Bilim ve Teknoloji” adlı altıncı temada altı farklı türde yazma etkinliği yer almaktadır. Bu etkinlikler beş farklı kazanımla ilişkilidir.

Tablo 15. 6. Sınıf Türkçe Ders Kitabı 7. Temada Yer Alan Yazma Etkinlikleri

\begin{tabular}{|c|c|c|c|}
\hline \multicolumn{4}{|c|}{ 7. TEMA: SANAT } \\
\hline Metin & $\begin{array}{l}\text { Etkinlik } \\
\text { Numarası }\end{array}$ & Etkinlik & İlgili Kazanım/Kazanımlar \\
\hline Çocuk ve Resim & 7. Etkinlik & $\begin{array}{l}\text { Görselden } \\
\text { hareketle } \quad \text { yazı } \\
\text { yazma }\end{array}$ & T.6.4.4. Yazma stratejilerini uygular. \\
\hline Yaz Sinemaları & 8. Etkinlik & Afiş hazırlama & T.6.4.14. Kısa metinler yazar. \\
\hline Yürekler & 7. Etkinlik & $\begin{array}{l}\text { Bilgilendirici } \\
\text { metin yazma }\end{array}$ & T.6.4.2. Bilgilendirici metin yazar. \\
\hline
\end{tabular}




\begin{tabular}{|c|c|c|c|}
\hline $\begin{array}{l}\text { Mozart ın Müziği } \\
\text { (Dinleme/izleme } \\
\text { metni) }\end{array}$ & 8. Etkinlik & $\begin{array}{l}\text { Metinden } \\
\text { hareketle yeni bir } \\
\text { metin oluşturma }\end{array}$ & T.6.4.4. Yazma stratejilerini uygular. \\
\hline
\end{tabular}

Tablo $15^{\prime}$ ten anlaşıldığı gibi "Sanat" adlı yedinci temada dört farklı türde yazma etkinliği yer almaktadır. Bu etkinlikler üç farklı kazanımla ilişkilidir.

Tablo 16. 6. Sınıf Türkçe Ders Kitabı 8. Temada Yer Alan Yazma Etkinlikleri

\begin{tabular}{|c|c|c|c|}
\hline \multicolumn{4}{|c|}{ 8. TEMA: VATANDAŞLIK } \\
\hline Metin & $\begin{array}{l}\text { Etkinlik } \\
\text { Numarası }\end{array}$ & Etkinlik & İïlgili Kazanım/Kazanımlar \\
\hline Kurtla Köpek & 12. Etkinlik & Şiir yazma & T.6.4.1. Şiir yazar. \\
\hline Nazilli Destanı & 6. Etkinlik & $\begin{array}{l}\text { Gezip gördüğü } \\
\text { yeri tanıtma yazısı }\end{array}$ & T.6.4.2. Bilgilendirici metin yazar. \\
\hline $\begin{array}{l}\text { Vatan Sevgisini } \\
\text { İçten Duyanlar }\end{array}$ & 6. Etkinlik & $\begin{array}{l}\text { Bilgilendirici } \\
\text { metin yazma }\end{array}$ & T.6.4.2. Bilgilendirici metin yazar. \\
\hline $\begin{array}{l}\text { Seyfi Dede } \\
\text { (Dinleme/izleme } \\
\text { metni) }\end{array}$ & 9. Etkinlik & $\begin{array}{l}\text { İş ilanı metni } \\
\text { yazma }\end{array}$ & T.6.4.14. Kisa metinler yazar. \\
\hline
\end{tabular}

Tablo 16' dan anlaşıldığı gibi "Vatandaşlık" adlı yedinci temada dört farklı türde yazma etkinliği yer almaktadır. Bu etkinlikler üç farklı kazanımla ilişkilidir.

6. sınıf ders kitabındaki yazma becerisine yönelik etkinliklerin, Türkçe Dersi Öğretim Programı'nda (MEB, 2019) yer alan 14 yazma becerisi kazanımından 7 tanesini içerdiği görülmüştür. En çok tekrar eden kazanım "T.6.4.4. Yazma stratejilerini uygular" kazanımıdır. Bununla birlikte "T.6.4.13. Formları yönergelerine uygun olarak doldurur" kazanımına bir kez yer verildiği görülmektedir. İlgili kazanım "Erdemler" temasında yer alan "İyilik Üzerine" metninin 7. etkinliğiyle ilişkilendirilmiştir. Bununla birlikte etkinliklerde hiç yer verilmeyen kazanımlar bulunmaktadır. Bunlar "T.6.4.5. Yazdıklarını desteklemek için gerektiğinde grafik ve tablo kullanır, T.6.4.7. Yazıların zenginleştirmek için atasözleri, deyimler ve özdeyişler kullanır, T.6.4.8. Yazdıklarının içeriğine uygun başlık belirler, T.6.4.9. Yazılarında uygun geçiş ve bağlantı ifadelerini kullanır, T.6.4.12. Yazdıklarında yabancı dillerden alınmış, dilimize henüz yerleşmemiş kelimelerin Türkçelerini kullanır." kazanımlarıdır.

6. sınıf ders kitabında ayrıca birden fazla yazma etkinliğine yer veren metinler de yer almaktadır. "Erdemler" temasında yer alan "İyilik Üzerine" metninde 7, 8 ve 9. etkinlikler yazma becerisi etkinlikleridir. Bununla beraber "Bilim ve Teknoloji" temasında yer alan "Büyük Keşifler" metnindeki 5 ve 6 . etkinliklerin yazma etkinliği olduğu saptanmıştır. Son olarak "Sanat" temasında yer alan "İçimdeki Müzik" isimli bir diğer metinde ise 9 ve 10. etkinliklerin yazma etkinliği olduğu tespit edilmiştir.

Türkçe Dersi Öğretim Programı (MEB, 2019) doğrultusunda 6. sınıflar düzeyinde dil bilgisi temelli etkinliklere yazma becerisi kazanımları içerisinde yer verilmiştir. İlgili etkinliklerde boşluk doldurma, açık uçlu soru cevaplama, eşleştirme, doğru/yanlış gibi çeşitli türler yer almaktadır.

6. sınıf ders kitabında yazma stratejilerinin kullanımına ağırlık veren etkinliklerde cümle düzeyinde yazma, karışık cümleleri düzenleme etkinliklerinin ön planda olduğu görülmektedir. 
Basitten karmaşığa ve öğrenci seviyesine uygunluk ilkeleri göz önüne alındığında ilgili etkinliklerin sayıca ön planda olmasıyla öğrencilerin cümle düzeyinde yazma becerisinde yetkinlik kazanmasının amaçlandığı görülmektedir. Ders kitapları öğrencilerin ilgili programda yer alan kazanımları edinebilmeleri açısından en temel kaynaktır. Bu açıdan bakıldığında yazma becerisine yönelik söz konusu kazanımlara yer verilmemesi o yaş seviyesindeki öğrencilerin ilgili kazanımları edinmesi açısından büyük bir eksikliğe neden olmaktadır. Yazma etkinliklerinin biçim özellikleri dikkate alındığında yazı türleri açısından hikâye edici metinlerin ön plana çıktığı görülmektedir. Sınıf seviyesine göre bu durum doğal karşılanabilir. Bunun yanında bilgilendirici metin ve şiir yazımı ile ilgili etkinlikler de yer almaktadır. Ancak ilgili etkinliklerin söz konusu metin türlerine yönelik farkındalık oluşturmak amacıyla ders kitabında yer aldığı söylenebilir. Söz konusu yazı türleri içerisinde şiirin en az yer verilen tür olduğu görülmektedir.

6. Sınıf Türkçe (Ekoyay Eğitim Yayıncılık) ders kitabındaki yazma etkinlikleri ilgili metinle konu ve tür olarak benzerlik göstermektedir. Metnin türü şiir ise devamında verilen yazma etkinliği de şiir türündedir. Bu durum öğrencide tür farkındalığının kazandırılması ve buna yönelik üretim becerilerinin geliştirilmesi açısından oldukça önemlidir.

\subsection{Sınıf Türkçe Ders Kitabı Yazma Etkinliklerinin İncelenmesi}

Özgün Yayıncılık tarafından hazırlanan "Ortaokul ve İmam Hatip Ortaokulu Türkçe 7. Sınıf" ders kitabında yer alan yazma etkinlikleri incelenmiştir. İnceleme sonucunda temalarda ne tür yazma etkinlikleri olduğu, bu etkinliklerin Türkçe dersi öğretim programında yer alan hangi kazanımla ilişkili olduğu tablolaştırılmıştır.

Tablo 17. 7. Sınıf Türkçe Ders Kitabı 1. Temada Yer Alan Yazma Etkinlikleri

\begin{tabular}{|c|c|c|c|}
\hline \multicolumn{4}{|c|}{ 1. TEMA: ERDEMLER } \\
\hline Metin & $\begin{array}{l}\text { Etkinlik } \\
\text { Numarası }\end{array}$ & Etkinlik & İlgili Kazanım/Kazanımlar \\
\hline $\begin{array}{l}\text { Karanfiller ve } \\
\text { Domates Suyu }\end{array}$ & 11. Etkinlik & Afiş hazırlama & $\begin{array}{l}\text { T.7.4.11. Kısa metinler yazar } \\
\text { T.7.4.6. Bir işi işlem basamaklarına } \\
\text { göre yazar }\end{array}$ \\
\hline Ninenin Kitab1 & 10. Etkinlik & $\begin{array}{l}\text { Kitap incelemesi } \\
\text { yazma }\end{array}$ & $\begin{array}{l}\text { T.7.4.2. Bilgilendirici metin yazar } \\
\text { T.7.4.6. Bir işi işlem basamaklarına } \\
\text { göre yazar }\end{array}$ \\
\hline $\begin{array}{l}\text { Baba, Bana Bir } \\
\text { Şiir Bul }\end{array}$ & 8. Etkinlik & Şiir yazma & $\begin{array}{l}\text { T.7.4.1. Şiir yazar } \\
\text { T.7.4.12. Yazdıklarının içeriğine } \\
\text { uygun başlık belirler } \\
\text { T.7.4.17. Yazdıklarını paylaşır }\end{array}$ \\
\hline $\begin{array}{l}\text { Akıllı K1z } \\
\text { (Dinleme/İzleme } \\
\text { Metni) }\end{array}$ & $\begin{array}{l}\text { 5. Etkinlik } \\
\text { 8. Etkinlik }\end{array}$ & $\begin{array}{l}\text { Dinlediği metni } \\
\text { özetleyip yazma } \\
\text { E-posta yazma }\end{array}$ & $\begin{array}{l}\text { T.7.4.4. Yazma stratejilerini uygular } \\
\text { T.7.4.11. Kısa metinler yazar }\end{array}$ \\
\hline
\end{tabular}

Tablo 17'den anlaşıldığı gibi "Erdemler" adlı birinci temada beş farklı türde yazma etkinliği yer almaktadır. Bu etkinlikler yedi farklı kazanımla ilişkilidir.

Tablo 18. 7. Sınıf Türkçe Ders Kitabı 2. Temada Yer Alan Yazma Etkinlikleri

\section{TEMA: MİLLÎ MÜCADELE VE ATATÜRK}




\begin{tabular}{|c|c|c|c|}
\hline Metin & $\begin{array}{l}\text { Etkinlik } \\
\text { Numarası }\end{array}$ & Etkinlik & İlgili Kazanım/Kazanımlar \\
\hline $\begin{array}{l}\text { Atatürk } \\
\text { Anıları }\end{array}$ & 9. Etkinlik & $\begin{array}{l}\text { Tanık olunan bir } \\
\text { olayı yazma }\end{array}$ & $\begin{array}{l}\text { T.7.4.3. Hikâye edici metin yazar } \\
\text { T.7.4.16. Yazdıklarını düzenler } \\
\text { T.7.4.17. Yazdıklarını paylaşır }\end{array}$ \\
\hline Koca Seyit & 6. Etkinlik & $\begin{array}{l}\text { Görselden } \\
\text { hareketle duygu } \\
\text { ve düşüncelerini } \\
\text { yazma }\end{array}$ & $\begin{array}{l}\text { T.7.4.2. Bilgilendirici metin yazar } \\
\text { T.7.4.15. Yazılarında uygun geçiş ve } \\
\text { bağlantı ifadelerini kullanır } \\
\text { T.7.4.12. Yazdıklarının içeriğine } \\
\text { uygun başlık belirler } \\
\text { T.7.4.17. Yazdıklarını paylaşır }\end{array}$ \\
\hline $\begin{array}{l}\text { Bir Mustafa } \\
\text { Kemal Vardı }\end{array}$ & 7. Etkinlik & Mektup yazma & $\begin{array}{l}\text { T.7.4.11. Kısa metinler yazar } \\
\text { T.7.4.17. Yazdıklarını paylaşır }\end{array}$ \\
\hline $\begin{array}{l}\text { Bayrağımızın } \\
\text { Altında } \\
\text { (Dinleme/İzleme } \\
\text { Metni) }\end{array}$ & 7. Etkinlik & Şiir yazma & T.7.4.1. Şiir yazar \\
\hline
\end{tabular}

Tablo 18'den anlaşıldığı gibi "Millî Mücadele ve Atatürk" adlı ikinci temada dört farklı türde yazma etkinliği yer almaktadır. Bu etkinlikler sekiz farklı kazanımla ilişkilidir.

Tablo 19. 7. Sınıf Türkçe Ders Kitabı 3. Temada Yer Alan Yazma Etkinlikleri

\begin{tabular}{|c|c|c|c|}
\hline \multicolumn{4}{|c|}{ 3. TEMA: DUYGULAR } \\
\hline Metin & $\begin{array}{l}\text { Etkinlik } \\
\text { Numarası }\end{array}$ & Etkinlik & İlgili Kazanım/Kazanımlar \\
\hline Meșe ile Saz & 7. Etkinlik & Fabl tamamlama & T.7.4.3. Hikâye edici metin yazar \\
\hline Küçük Çocuk & 7. Etkinlik & $\begin{array}{l}\text { Özdeyişten } \\
\text { hareketle yazma }\end{array}$ & $\begin{array}{l}\text { T.7.4.4. Yazma stratejilerini uygular } \\
\text { T.7.4.6. Bir işi işlem basamaklarına } \\
\text { göre yazar } \\
\text { T.7.4.12. Yazdıklarının içeriğine } \\
\text { uygun başlık belirler } \\
\text { T.7.4.16. Yazdıklarını düzenler } \\
\text { T.7.4.17. Yazdıklarını paylaşır }\end{array}$ \\
\hline Y1kmak Kolay & - & - & - \\
\hline $\begin{array}{l}\text { Sözcüklerin Gücü } \\
\text { (Dinleme/İzleme } \\
\text { Metni) }\end{array}$ & $\begin{array}{l}\text { 3. Etkinlik } \\
\text { 4. Etkinlik } \\
\text { 9. Etkinlik }\end{array}$ & $\begin{array}{l}\text { Özetleyip yazma } \\
\text { Başkasının yerine } \\
\text { koyup yazma } \\
\text { Dilekçe yazma }\end{array}$ & T.7.4.11. Kısa metinler yazar \\
\hline
\end{tabular}

Tablo 19'dan anlaşıldığı gibi "Duygular" adlı üçüncü temada beş farklı türde yazma etkinliği yer almaktadır. "Yıkmak Kolay" adlı metnin etkinlikleri arasında yazma etkinliği bulunmamaktadır. Diğer metinlerde yer yazma etkinlikleri sekiz farklı kazanımla ilişkilidir.

Tablo 20. 7. Sınıf Türkçe Ders Kitabı 4. Temada Yer Alan Yazma Etkinlikleri

\section{TEMA: MİLLÎ KÜLTÜRÜMÜZ}




\begin{tabular}{|c|c|c|c|}
\hline Metin & $\begin{array}{l}\text { Etkinlik } \\
\text { Numaras1 }\end{array}$ & Etkinlik & İlgili Kazanım/Kazanımlar \\
\hline $\begin{array}{l}\text { İstiklâl Marşı'nın } \\
\text { Kabulü }\end{array}$ & 7. Etkinlik & Biyografi yazma & T.7.4.2. Bilgilendirici metin yazar \\
\hline $\begin{array}{l}\text { Büyük Mimar } \\
\text { Koca Sinan }\end{array}$ & 9. Etkinlik & Gezi yazısı yazma & T.7.4.3. Hikâye edici metin yazar \\
\hline Yurt Türküsü & 4. Etkinlik & $\begin{array}{l}\text { Blog yazısı } \\
\text { düzenleme }\end{array}$ & $\begin{array}{l}\text { T.7.4.11. Kısa metinler yazar } \\
\text { T.7.4.17. Yazdıklarını paylaşır }\end{array}$ \\
\hline Anadolu Üstüne & 8. Etkinlik & $\begin{array}{l}\text { Bilgilendirici } \\
\text { metin yazma }\end{array}$ & $\begin{array}{l}\text { T.7.4.2. Bilgilendirici metin yazar } \\
\text { T.7.4.15. Yazılarında uygun geçiş ve } \\
\text { bağlantı ifadelerini kullanır } \\
\text { T.7.4.16. Yazdıklarını düzenler } \\
\text { T.7.4.17. Yazdıklarını paylaşır }\end{array}$ \\
\hline
\end{tabular}

Tablo 20'den anlaşıldığı gibi "Millî Kültürümüz" adlı dördüncü temada dört farklı türde yazma etkinliği yer almaktadır. Bu etkinlikler altı farklı kazanımla ilişkilidir.

Tablo 21. 7. Sınıf Türkçe Ders Kitabı 5. Temada Yer Alan Yazma Etkinlikleri

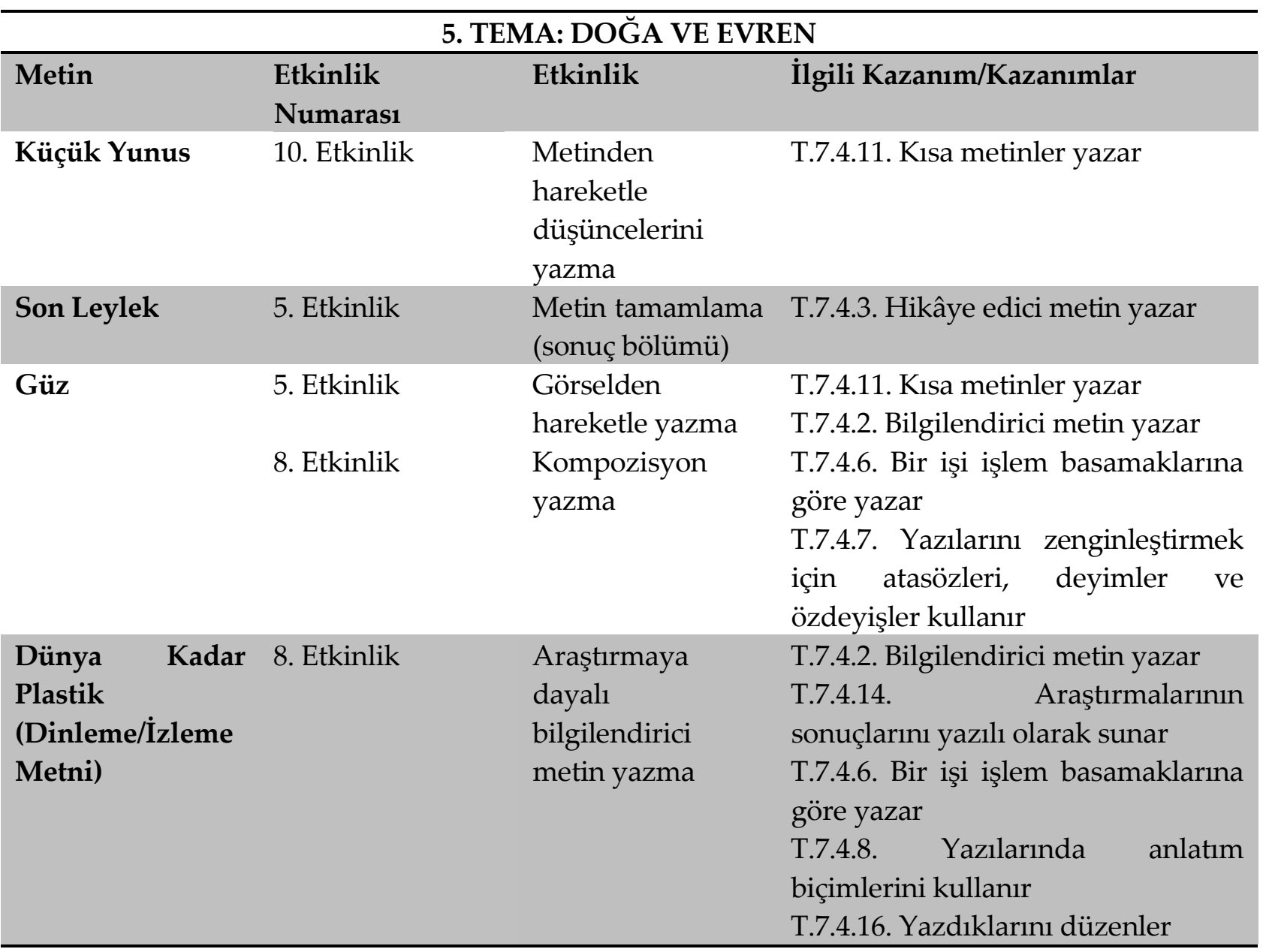

Tablo 21'den anlaşıldığı gibi "Doğa ve Evren" adlı beşinci temada dört farklı türde yazma etkinliği yer almaktadır. Bu etkinlikler sekiz farklı kazanımla ilişkilidir.

Tablo 22. 7. Sınıf Türkçe Ders Kitabı 6. Temada Yer Alan Yazma Etkinlikleri 


\begin{tabular}{|c|c|c|c|}
\hline \multicolumn{4}{|c|}{ 6. TEMA: SANAT } \\
\hline Metin & $\begin{array}{l}\text { Etkinlik } \\
\text { Numarası }\end{array}$ & Etkinlik & İlgili Kazanım/Kazanımlar \\
\hline Anadolu Davulu & 10. Etkinlik & $\begin{array}{l}\text { Tanitim } \quad \text { yazisı } \\
\text { yazma }\end{array}$ & $\begin{array}{l}\text { T.7.4.6. Bir işi işlem basamaklarına } \\
\text { göre yazar } \\
\text { T.7.4.11. Kısa metinler yazar }\end{array}$ \\
\hline Sazıma & 5. Etkinlik & E-posta yazma & T.7.4.11. Kisa metinler yazar \\
\hline $\begin{array}{l}\text { Karagöz } \\
\text { Hacivat }\end{array}$ & 8. Etkinlik & $\begin{array}{l}\text { Verilen unsurları } \\
\text { kullanarak hikâye } \\
\text { yazma }\end{array}$ & $\begin{array}{l}\text { T.7.4.3. Hikâye edici metin yazar } \\
\text { T.7.4.12. Yazdıklarının içeriğine } \\
\text { uygun başlık belirler } \\
\text { T.7.4.8. Yazılarında anlatım } \\
\text { biçimlerini kullanır }\end{array}$ \\
\hline $\begin{array}{l}\text { Türkiye'de } \\
\text { Geleneksel } \\
\text { Sanatlar } \\
\text { (Dinleme/İzleme } \\
\text { Metni) }\end{array}$ & 7. Etkinlik & $\begin{array}{l}\text { Açıklayıcı metin } \\
\text { yazma } \\
\text { Form doldurma }\end{array}$ & $\begin{array}{l}\text { T.7.4.2. Bilgilendirici metin yazar } \\
\text { T.7.4.7. Yazılarını zenginleştirmek } \\
\text { için atasözleri, deyimler ve } \\
\text { özdeyişler kullanır } \\
\text { T.7.4.10. Formları yönergelerine } \\
\text { uygun doldurur }\end{array}$ \\
\hline
\end{tabular}

Tablo 22'den anlaşıldığı gibi "Sanat" adlı altıncı temada beş farklı türde yazma etkinliği yer almaktadır. Bu etkinlikler sekiz farklı kazanımla ilişkilidir.

Tablo 23. 7. Sınıf Türkçe Ders Kitabı 7. Temada Yer Alan Yazma Etkinlikleri

\begin{tabular}{|c|c|c|c|}
\hline \multicolumn{4}{|c|}{ 7. TEMA: KİŞİSEL GELİŞİM } \\
\hline Metin & $\begin{array}{l}\text { Etkinlik } \\
\text { Numarası }\end{array}$ & Etkinlik & İlgili Kazanım/Kazanımlar \\
\hline Ağaç ve Sen & $\begin{array}{l}\text { 4. Etkinlik } \\
\text { 5. Etkinlik }\end{array}$ & $\begin{array}{l}\text { Düş̧üncelerini } \\
\text { yazma } \\
\text { Verilen sözcükleri } \\
\text { kullanarak şiir } \\
\text { yazma }\end{array}$ & $\begin{array}{l}\text { T.7.4.11. Kısa metinler yazar } \\
\text { T.7.4.1. Şiir yazar }\end{array}$ \\
\hline Bazı İnsanlar & $\begin{array}{l}\text { 8. Etkinlik } \\
\text { 12. Etkinlik }\end{array}$ & $\begin{array}{l}\text { Görselden } \\
\text { hareketle yazma } \\
\text { Kişisel } \\
\text { özelliklerini } \\
\text { tanitan yazı } \\
\text { yazma }\end{array}$ & T.7.4.11. Kisa metinler yazar \\
\hline $\begin{array}{l}\text { Karamsar } r \\
\text { İyimser } \\
\text { Açısı }\end{array}$ & $\begin{array}{l}\text { 4. Etkinlik } \\
\text { 8. Etkinlik }\end{array}$ & $\begin{array}{l}\text { Özetleyip yazma } \\
\text { Verilen } \\
\text { kavramlardan } \\
\text { hareketle hikâye } \\
\text { yazma }\end{array}$ & $\begin{array}{l}\text { T.7.4.11 Kısa metinler yazar } \\
\text { T.7.4.3. Hikâye edici metin yazar } \\
\text { T.7.4.8. Yazılarında anlatım } \\
\text { biçimlerini kullanır } \\
\text { T.7.4.12. Yazdıklarının içeriğine } \\
\text { uygun başlık belirler }\end{array}$ \\
\hline $\begin{array}{l}\text { Illetişim } \\
\text { Becerilerimiz }\end{array}$ & $\begin{array}{l}\text { 4. Etkinlik } \\
\text { 8. Etkinlik }\end{array}$ & $\begin{array}{l}\text { Görselden } \\
\text { hareketle } \\
\text { yazma }\end{array}$ & $\begin{array}{l}\text { T.7.4.4. Yazma stratejilerini uygular } \\
\text { T.7.4.15. Yazılarında uygun geçiş ve } \\
\text { bağlantı ifadelerini kullanır }\end{array}$ \\
\hline
\end{tabular}




\begin{tabular}{llll}
\hline $\begin{array}{l}\text { (Dinleme/İzleme } \\
\text { Metni) }\end{array}$ & $\begin{array}{l}\text { Görselden } \\
\text { hareketle } \\
\text { yazma }\end{array}$ & yazı & $\begin{array}{l}\text { T.7.4.16. Yazdıklarını düzenler } \\
\text { T.7.4.17. Yazdıklarını paylaşır }\end{array}$ \\
\hline
\end{tabular}

Tablo 23'ten anlaşıldığı gibi "Kişisel Gelişim" adlı yedinci temada sekiz farklı türde yazma etkinliği yer almaktadır. Bu etkinlikler dokuz farklı kazanımla ilişkilidir.

Tablo 24. 7. Sınıf Türkçe Ders Kitabı 8. Temada Yer Alan Yazma Etkinlikleri

\begin{tabular}{|c|c|c|c|}
\hline \multicolumn{4}{|c|}{ 8. TEMA: BİLIM VE TEKNOLOJİ } \\
\hline Metin & $\begin{array}{l}\text { Etkinlik } \\
\text { Numarası }\end{array}$ & Etkinlik & İlgili Kazanım/Kazanımlar \\
\hline $\begin{array}{l}\text { Ampulün İlk } \\
\text { Yanışı }\end{array}$ & $\begin{array}{l}\text { 5. Etkinlik } \\
\text { 8. Etkinlik }\end{array}$ & $\begin{array}{l}\text { Düşüncelerini } \\
\text { yazma } \\
\text { Düşüncelerini } \\
\text { yazma }\end{array}$ & $\begin{array}{l}\text { T.7.4.11. Kısa metinler yazar } \\
\text { T.7.4.16. Yazdıklarını düzenler }\end{array}$ \\
\hline İbni Sina & $\begin{array}{l}\text { 3. Etkinlik } \\
\text { 9. Etkinlik }\end{array}$ & $\begin{array}{l}\text { İzlemeye dayalı } \\
\text { yazma } \\
\text { Özdeyişten } \\
\text { hareketle } \\
\text { yazma }\end{array}$ & $\begin{array}{l}\text { T.7.4.11. Kisa metinler yazar } \\
\text { T.7.4.4. Yazma stratejilerini uygular }\end{array}$ \\
\hline $\begin{array}{l}\text { Islikla } \\
\text { Haberleşenler }\end{array}$ & 7. Etkinlik & $\begin{array}{l}\text { Görselden } \\
\text { hareketle kisa } \\
\text { metin yazma }\end{array}$ & T.7.4.11. Kisa metinler yazar \\
\hline $\begin{array}{l}\text { Elinizin } \\
\text { Altındaki Dünya } \\
\text { (Dinleme /İzleme } \\
\text { Metni) }\end{array}$ & - & - & \\
\hline
\end{tabular}

Tablo 24'ten anlaşıldığı gibi "Duygular" adlı üçüncü temada üç farklı türde yazma etkinliği yer almaktadır. "Elinizin Altındaki Dünya" adlı dinleme/izleme metninin etkinlikleri arasında yazma etkinliği bulunmamaktadır. Diğer metinlerde yer yazma etkinlikleri üç farklı kazanımla ilişkilidir.

7. Sınıf Türkçe (Özgün Matbaacılık) ders kitabındaki yazma becerisine yönelik etkinlikler, Türkçe Dersi Öğretim Programı'nda (MEB, 2019) yer alan 17 yazma becerisi kazanımından 14 tanesine doğrudan yer verildiği görülmektedir. "T.7.4.5. Anlatımı desteklemek için grafik ve tablo kullanır, T.7.4.9. Yazdıklarında yabancı dillerden alınmış, dilimize henüz yerleşmemiş kelimelerin Türkçelerini kullanır, T.7.4.13. Ek fiili işlevlerine uygun olarak kullanır." kazanımlarının belirgin bir şekilde yer almadığ 1 dikkat çekmektedir. Buna karşın "Doğa ve Evren" temasında yer alan "Son Leylek" metninin sonunda bir sonraki metne hazırlık çalışmasında verilen yazma yönergesinde "Ülkemizde küresel ısınmanın etkilerini görüyor musunuz? Araştırmanızdan hareketle düşüncelerinizi ifade eden bilgilendirici bir metin yazınız. Yazınızı grafik, tablo ve çizelgeyle destekleyiniz." şeklinde bir yönlendirme yapılmıştır. Öğrencinin okuldan bağımsız gerçekleştireceği bir çalışmada kitabın hiçbir yerinde uygulanmamış bir yazma kazanımının verilmesi doğru değildir. Öğretmen rehberliğinde yapılacak çalışmalarda yapılmış bir çalışma öğrencinin bireysel olarak yapacağı başka çalışmalara ışık tutacak nitelikte olmalıdır. 
7. sınıf yazma kazanımları içerisinde dil bilgisine yönelik sadece T.7.4.13. Ek fiili işlevlerine uygun olarak kullanır." kazanımı yer almaktadır. "T.7.3.9. Çekim eklerinin işlevlerini ayırt eder, T.7.3.10. Basit, türemiş ve birleşik fiilleri ayırt eder, T.7.3.11. Zarfların metnin anlamına olan katkısını açıklar, T.7.3.12. Fiillerin anlam özelliklerini fark eder, T.7.3.13. Anlatım bozuklukların tespit eder." kazanımları ise okuma/söz varlığı başlığı altında ele alınmıştır.

7. sınıf ders kitabında afiş hazırlamadan elektronik postaya, şiirden hikâyeye, bilgilendirici metinden tanıtım yazısına kadar birçok farklı türde yazma etkinliği yer almaktadır. Bu etkinlikler içerisinde "T.7.4.11. Kısa metinler yazar." kazanımının en çok tekrar eden kazanım olduğu görülmektedir. Bunun sebebini de öğrencilerin yaş ve gelişim düzeylerine dayalı olarak daha kısa metinler yazma eğiliminde olduklarına bağlamak mümkündür. Tür bağlamında bakıldığında ise düşüncelerini yazma, görselden hareketle duygu ve/veya düşüncelerini yazma, form doldurma, tanıtım yazısı, kitap incelemesi gibi bilgilendirici ağırlıklı türlerin öne çıktığı; öyküleyici metin ve şiir yazmanın ise daha az yer bulduğu görülmektedir.

\subsection{Sınıf Türkçe Ders Kitabı Yazma Etkinliklerinin İncelenmesi}

Millî Eğitim Bakanlığı tarafından hazırlanan "Ortaokul ve İmam Hatip Ortaokulu Türkçe 8. Sınıf" ders kitabında yer alan yazma etkinlikleri incelenmiştir. İnceleme sonucunda temalarda ne tür yazma etkinlikleri olduğu, bu etkinliklerin Türkçe dersi öğretim programinda yer alan hangi kazanımla ilişkili olduğu tablolaştırılmıştır.

Tablo 25. 8. Sınıf Türkçe Ders Kitabı 1. Temada Yer Alan Yazma Etkinlikleri

\begin{tabular}{|c|c|c|c|}
\hline \multicolumn{4}{|c|}{ 1. TEMA: ERDEMLER } \\
\hline Metin & $\begin{array}{l}\text { Etkinlik } \\
\text { Numarası }\end{array}$ & Etkinlik & İlgili Kazanım/Kazanımlar \\
\hline $\begin{array}{ll}\text { İyimserlik } & \text { ve } \\
\text { Kötümserlik } & \\
\text { Üzerine } & \end{array}$ & 9. Etkinlik & $\begin{array}{l}\text { Bilgilendirici } \\
\text { metin yazma }\end{array}$ & $\begin{array}{l}\text { T.8.4.2. Bilgilendirici metin yazar } \\
\text { T.8.4.13. Yazdıklarının içeriğine } \\
\text { uygun başlık belirler } \\
\text { T.8.4.6 Bir işi işlem basamaklarına } \\
\text { göre yazma } \\
\text { T.8.4.16. Yazdıklarını düzenler }\end{array}$ \\
\hline Kaşağ1 & 8. Etkinlik & $\begin{array}{l}\text { Hikâye edici } \\
\text { metin yazar. }\end{array}$ & $\begin{array}{l}\text { T.8.4.3. Hikâye edici metin yazar } \\
\text { T.8.4.13. Yazdıklarının içeriğine } \\
\text { uygun başlık belirler } \\
\text { T.8.4.16. Yazdıklarını düzenler } \\
\text { T.8.4.17. Yazdıklarını paylaşır }\end{array}$ \\
\hline İnsanla Güzel & 8. Etkinlik & $\begin{array}{l}\text { Bilgilendirici } \\
\text { metin yazma }\end{array}$ & $\begin{array}{l}\text { T.8.4.2. Bilgilendirici metin yazar } \\
\text { T.8.4.6 Bir işi işlem basamaklarına } \\
\text { göre yazma } \\
\text { T.8.4.7. Yazılarını zenginleştirmek } \\
\text { için atasözleri, deyimler ve } \\
\text { özdeyişler kullanır } \\
\text { T.8.4.13. Yazdıklarının içeriğine } \\
\text { uygun başlık belirler } \\
\text { T.8.4.16. Yazdıklarını düzenler }\end{array}$ \\
\hline
\end{tabular}




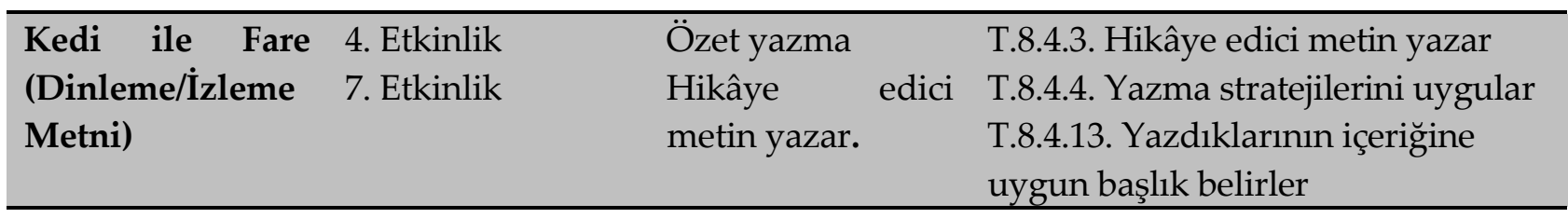

Tablo 25'ten anlaşıldığı gibi "Erdemler" adlı birinci temada beş farklı türde yazma etkinliği yer almaktadır. Bu etkinlikler dokuz farklı kazanımla ilişkilidir.

Tablo 26. 8. Sınıf Türkçe Ders Kitabı 2. Temada Yer Alan Yazma Etkinlikleri

\section{TEMA: MİLLÎ MÜCADELE VE ATATÜRK}

\begin{tabular}{|c|c|c|c|}
\hline Metin & $\begin{array}{l}\text { Etkinlik } \\
\text { Numarası }\end{array}$ & Etkinlik & İlgili Kazanım/Kazanımlar \\
\hline $\begin{array}{l}\text { Bayrağımızın } \\
\text { Altında }\end{array}$ & 7. Etkinlik & Şiir yazma & $\begin{array}{l}\text { T.8.4.1. Şiir yazar } \\
\text { T.8.4.13. Yazdıklarının içeriğine } \\
\text { uygun başlık belirler } \\
\text { T.8.4.17. Yazdıklarını paylaşır }\end{array}$ \\
\hline Atatürk ve Müzik & 7. Etkinlik & $\begin{array}{l}\text { Yabancı dillerden } \\
\text { alınmış, dilimize } \\
\text { henüz } \\
\text { yerleşmemiş } \\
\text { kelimelerin } \\
\text { Türkçelerini } \\
\text { kullanma }\end{array}$ & $\begin{array}{l}\text { T.8.4.10. Yazdıklarında yabancı } \\
\text { dillerden alınmış, dilimize henüz } \\
\text { yerleşmemiş kelimelerin } \\
\text { Türkçelerini kullanır }\end{array}$ \\
\hline $\begin{array}{l}\text { Kinali Ali'nin } \\
\text { Mektubu }\end{array}$ & 8. Etkinlik & $\begin{array}{l}\text { Bilgilendirici } \\
\text { metin yazma }\end{array}$ & $\begin{array}{l}\text { T.8.4.2. Bilgilendirici metin yazar } \\
\text { T.8.4.14. Araştırmalarının } \\
\text { sonuçlarını yazılı olarak sunar } \\
\text { T.8.4.13. Yazdıklarının içeriğine } \\
\text { uygun başlık belirler }\end{array}$ \\
\hline $\begin{array}{l}\text { Atatürk'ü } \\
\text { Gördüm } \\
\text { (Dinleme/İzleme } \\
\text { Metni) }\end{array}$ & $\begin{array}{l}\text { 3. Etkinlik } \\
\text { 8. Etkinlik }\end{array}$ & $\begin{array}{l}\text { Özet yazma } \\
\text { Anı yazma }\end{array}$ & $\begin{array}{l}\text { T.8.4.4. Yazma stratejilerini uygular } \\
\text { T.8.4.2. Bilgilendirici metin yazar } \\
\text { T.8.4.13. Yazdıklarının içeriğine } \\
\text { uygun başlık belirler }\end{array}$ \\
\hline
\end{tabular}

Tablo 26'dan anlaşıldığı gibi "Millî Mücadele ve Atatürk" adlı birinci temada beş farklı türde yazma etkinliği yer almaktadır. Bu etkinlikler yedi farklı kazanımla ilişkilidir.

Tablo 27. 8. Sınıf Türkçe Ders Kitabı 3. Temada Yer Alan Yazma Etkinlikleri

\section{TEMA: BILIIM VE TEKNOLOJI}




\begin{tabular}{|c|c|c|c|}
\hline Metin & $\begin{array}{l}\text { Etkinlik } \\
\text { Numarası }\end{array}$ & Etkinlik & İlgili Kazanım/Kazanımlar \\
\hline $\begin{array}{l}\text { Gündelik } \\
\text { Hayatımızda } \\
\text { Hastalıklar }\end{array}$ & $\begin{array}{l}\text { 9. Etkinlik } \\
\text { E- }\end{array}$ & $\begin{array}{l}\text { Görselden } \\
\text { hareketle metin } \\
\text { oluşturma }\end{array}$ & T.8.4.4. Yazma stratejilerini uygular \\
\hline
\end{tabular}

\section{Simit ve Peynir'le \\ Bilim İnsanı \\ Öyküleri \\ Parktaki Bilim}

7. Etkinlik

8. Etkinlik

Uzay Giysileri
(Dinleme/İzleme

Metni)

\begin{abstract}
Hikâye
tamamlama
\end{abstract}

Bilgilendirici

metin yazma
T.8.4.3. Hikâye edici metin yazar

T.8.4.13. Yazdıklarının içeriğine uygun başlık belirler

T.8.4.2. Bilgilendirici metin yazar. T.8.4.14. Araştırmalarının sonuçlarını yazılı olarak sunar

Tablo 27'den anlaşıldığı gibi "Bilim ve Teknoloji” adlı üçüncü temada üç farklı türde yazma etkinliği yer almaktadır. "Simit ve Peynir'le Bilim İnsanı Öyküleri" adlı metnin etkinlikleri arasında yazma etkinliği bulunmamaktadır. Diğer metinlerdeki etkinlikler beş farklı kazanımla ilişkilidir.

Tablo 28. 8. Sınıf Türkçe Ders Kitabı 4. Temada Yer Alan Yazma Etkinlikleri

\section{TEMA: BİREY VE TOPLUM}

\begin{tabular}{|c|c|c|c|}
\hline Metin & $\begin{array}{l}\text { Etkinlik } \\
\text { Numarası }\end{array}$ & Etkinlik & İlgili Kazanım/Kazanımlar \\
\hline Kaldırımlar & 7. Etkinlik & Şiir yazma & $\begin{array}{l}\text { T.8.4.1. Şiir yazar } \\
\text { T.8.4.13. Yazdıklarının içeriğine } \\
\text { uygun başlık belirler } \\
\text { T.8.4.17. Yazdıklarını paylaşır }\end{array}$ \\
\hline Portakal & 6. Etkinlik & Günlük yazma & T.8.4.4. Yazma stratejilerini uygular \\
\hline $\begin{array}{l}\text { Dilimiz Kuşatma } \\
\text { Altında }\end{array}$ & 8. Etkinlik & $\begin{array}{l}\text { Görselden } \\
\text { hareketle } \\
\text { bilgilendirici } \\
\text { metin yazma }\end{array}$ & $\begin{array}{l}\text { T.8.4.2. Bilgilendirici metin yazar } \\
\text { T.8.4.4. Yazma stratejilerini uygular }\end{array}$ \\
\hline $\begin{array}{l}\text { Karanlığın Rengi } \\
\text { Beyaz } \\
\text { (Dinleme/İzleme } \\
\text { Metni) }\end{array}$ & 5. Etkinlik & $\begin{array}{l}\text { Empati } \\
\text { duygusuyla } \\
\text { hikâye edici metin } \\
\text { yazma }\end{array}$ & $\begin{array}{l}\text { T.8.4.3. Hikâye edici metin yazar } \\
\text { T.8.4.13. Yazdıklarının içeriğine } \\
\text { uygun başlık belirler }\end{array}$ \\
\hline
\end{tabular}

Tablo 28'den anlaşıldığ 1 gibi "Birey ve Toplum" adlı üçüncü temada dört farklı türde yazma etkinliği yer almaktadır. Bu etkinlikler altı farklı kazanımla ilişkilidir.

Tablo 29. 8. Sınıf Türkçe Ders Kitabı 5. Temada Yer Alan Yazma Etkinlikleri

\section{TEMA: ZAMAN VE MEKÂN}




\begin{tabular}{|c|c|c|c|}
\hline Metin & $\begin{array}{l}\text { Etkinlik } \\
\text { Numaras1 }\end{array}$ & Etkinlik & İlgili Kazanım/Kazanımlar \\
\hline Eşref Saat & 7. Etkinlik & Hikâye yazma & T.8.4.3. Hikâye edici metin yazar \\
\hline Türkiye & 7. Etkinlik & $\begin{array}{l}\text { Görselden } \\
\text { hareketle şiir } \\
\text { yazma }\end{array}$ & $\begin{array}{l}\text { T.8.4.1. Şiir yazar } \\
\text { T.8.4.13. Yazdıklarının içeriğine } \\
\text { uygun başlık belirler } \\
\text { T.8.4.17. Yazdıklarını paylaşır }\end{array}$ \\
\hline Peri Bacaları & 5. Etkinlik & Gezi yazısı yazma & $\begin{array}{l}\text { T.8.4.12. Kısa metinler yazar } \\
\text { T.8.4.13. Yazdıklarının içeriğine } \\
\text { uygun başlık belirler }\end{array}$ \\
\hline $\begin{array}{l}\text { Robinson Crusoe } \\
\text { (Dinleme/İzleme } \\
\text { Metni) }\end{array}$ & $\begin{array}{l}\text { 3. Etkinlik } \\
\text { 4. Etkinlik }\end{array}$ & $\begin{array}{l}\text { Özetleyerek } \\
\text { yazma } \\
\text { Tahminlerden } \\
\text { hareketle metin } \\
\text { tamamlama }\end{array}$ & T.8.4.4. Yazma stratejilerini uygular \\
\hline
\end{tabular}

Tablo 29'dan anlaşıldığı gibi "Zaman ve Mekân" adlı beşinci temada beş farklı türde yazma etkinliği yer almaktadır. Bu etkinlikler altı farklı kazanımla ilişkilidir.

Tablo 30. 8. Sınıf Türkçe Ders Kitabı 6. Temada Yer Alan Yazma Etkinlikleri

\begin{tabular}{|c|c|c|c|}
\hline \multicolumn{4}{|c|}{ 6. TEMA: MİLLÎ KÜLTÜRÜMÜZ } \\
\hline Metin & $\begin{array}{l}\text { Etkinlik } \\
\text { Numarası }\end{array}$ & Etkinlik & İlgili Kazanım/Kazanımlar \\
\hline Göç Destanı & 7. Etkinlik & $\begin{array}{l}\text { Mizahi ögelerden } \\
\text { faydalanarak } \\
\text { hikâye yazma }\end{array}$ & $\begin{array}{l}\text { T.8.4.3. Hikâye edici metin yazar } \\
\text { T.8.4.8. Yazılarında mizahi ögeler } \\
\text { kullanır } \\
\text { T.8.4.13. Yazdıklarının içeriğine } \\
\text { uygun başlık belirler }\end{array}$ \\
\hline $\begin{array}{l}\text { Vatan Sevgisini } \\
\text { İçten Duyanlar }\end{array}$ & $\begin{array}{l}\text { 7. Etkinlik } \\
\text { 9. Etkinlik }\end{array}$ & $\begin{array}{l}\text { Kisa metin yazma } \\
\text { Bilgilendirici } \\
\text { metin yazma }\end{array}$ & $\begin{array}{l}\text { T.8.4.2. Bilgilendirici metin yazar } \\
\text { T.8.4.15. Yazılarında uygun geçiş ve } \\
\text { bağlantı ifadelerini kullanır. }\end{array}$ \\
\hline Bir Fincan Kahve & $\begin{array}{l}\text { 4. Etkinlik } \\
\text { 7. Etkinlik }\end{array}$ & $\begin{array}{l}\text { Olayları akış } \\
\text { sırasına göre } \\
\text { yazma } \\
\text { Form doldurma }\end{array}$ & $\begin{array}{l}\text { T.8.4.6. Bir işi işlem basamaklarına } \\
\text { göre yazar } \\
\text { T.8.4.11. Formları yönergelerine } \\
\text { uygun doldurur }\end{array}$ \\
\hline $\begin{array}{l}\text { K1z Kulesi } \\
\text { (Dinleme/İzleme } \\
\text { Metni) }\end{array}$ & 9. Etkinlik & $\begin{array}{l}\text { Yabancı } \\
\text { sözcüklerin yerine } \\
\text { Türkçelerini } \\
\text { kullanma } \\
\text { Form doldurma }\end{array}$ & $\begin{array}{l}\text { T.8.4.10. Yazdıklarında yabancı } \\
\text { dillerden alınmıs, dilimize henüz } \\
\text { yerleşmemiş kelimelerin } \\
\text { Türkçelerini kullanır } \\
\text { T.8.4.11. Formları yönergelerine } \\
\text { uygun doldurur }\end{array}$ \\
\hline
\end{tabular}

Tablo 30'dan anlaşıldığı gibi "Millî Kültürümüz" adlı altıncı temada yedi farklı türde yazma etkinliği yer almaktadır. Bu etkinlikler sekiz farklı kazanımla ilişkilidir.

Tablo 31. 8. Sınıf Türkçe Ders Kitabı 7. Temada Yer Alan Yazma Etkinlikleri 


\section{TEMA: DOĞA VE EVREN}

\begin{tabular}{|c|c|c|c|}
\hline Metin & $\begin{array}{l}\text { Etkinlik } \\
\text { Numarası }\end{array}$ & Etkinlik & İlgili Kazanım/Kazanımlar \\
\hline \multirow[t]{2}{*}{ Yilkı Atı } & 6. Etkinlik & $\begin{array}{l}\text { Betimlemelerden } \\
\text { faydalanarak } \\
\text { cümle kurma }\end{array}$ & $\begin{array}{l}\text { T.8.4.9. Yazılarında anlatım } \\
\text { biçimlerini kullanır } \\
\text { T.8.4.3. Hikâye edici metin yazar }\end{array}$ \\
\hline & 10.Etkinlik & Hikâye yazma & $\begin{array}{l}\text { T.8.4.13. Yazdıklarının içeriğine } \\
\text { uygun başlık belirler }\end{array}$ \\
\hline Rüzgâr & 7. Etkinlik & Şiir yazma & $\begin{array}{l}\text { T.8.4.1. Şiir yazar } \\
\text { T.8.4.13. Yazdıklarının içeriğine } \\
\text { uygun başlık belirler }\end{array}$ \\
\hline $\begin{array}{l}\text { Gündüzünü } \\
\text { Kaybeden Kuş }\end{array}$ & 8. Etkinlik & $\begin{array}{l}\text { Bilgilendirici } \\
\text { metin yazma }\end{array}$ & $\begin{array}{l}\text { T.8.4.5. Anlatımı desteklemek için } \\
\text { grafik ve tablo kullanır } \\
\text { T.8.4.14. Araştırmalarının } \\
\text { sonuçlarını yazılı olarak sunar }\end{array}$ \\
\hline $\begin{array}{l}\text { Hava Kirliliği } \\
\text { (Dinleme/İzleme } \\
\text { Metni) }\end{array}$ & 8. Etkinlik & $\begin{array}{l}\text { Haber metni } \\
\text { yazma }\end{array}$ & T.8.4.12. Kisa metinler yazar \\
\hline
\end{tabular}

Tablo 31'den anlaşıldığı gibi "Doğa ve Evren" adlı yedinci temada beş farklı türde yazma etkinliği yer almaktadır. Bu etkinlikler yedi farklı kazanımla ilişkilidir.

Tablo 32. 8. Sınıf Türkçe Ders Kitabı 8. Temada Yer Alan Yazma Etkinlikleri

\begin{tabular}{|c|c|c|c|}
\hline \multicolumn{4}{|c|}{ 8. TEMA: VATANDAŞLIK } \\
\hline Metin & $\begin{array}{l}\text { Etkinlik } \\
\text { Numaras1 }\end{array}$ & Etkinlik & İlgili Kazanım/Kazanımlar \\
\hline $\begin{array}{l}\text { Haritada } \quad \text { Bir } \\
\text { Nokta }\end{array}$ & 9. Etkinlik & $\begin{array}{l}\text { Görselden } \\
\text { hareketle yazma }\end{array}$ & T.8.4.2. Bilgilendirici metin yazar \\
\hline Yaşamaya Dair & 7. Etkinlik & $\begin{array}{l}\text { Şiirden hareketle } \\
\text { bilgilendirici } \\
\text { metin yazma }\end{array}$ & $\begin{array}{l}\text { T.8.4.2. Bilgilendirici metin yazar } \\
\text { T.8.4.13. Yazdıklarının içeriğine } \\
\text { uygun başlık belirler }\end{array}$ \\
\hline $\begin{array}{l}\text { Kalbim } \\
\text { Rumeli'de Kaldı }\end{array}$ & $\begin{array}{l}\text { 4. Etkinlik } \\
\text { 8. Etkinlik }\end{array}$ & $\begin{array}{l}\text { Özetleyerek } \\
\text { yazma } \\
\text { Bilgilendirici } \\
\text { metin yazma }\end{array}$ & $\begin{array}{l}\text { T.8.4.12. Kısa metinler yazar } \\
\text { T.8.4.14. Araştırmalarının } \\
\text { sonuçlarını yazılı olarak sunar } \\
\text { T.8.4.17. Yazdıklarını paylaşır }\end{array}$ \\
\hline $\begin{array}{l}\text { Zeytinyağı } \\
\text { Üretimi (Dinleme } \\
\text { /İzleme Metni) }\end{array}$ & 7. Etkinlik & $\begin{array}{l}\text { Tablo } \\
\text { grafiklerden } \\
\text { hareketle } \\
\text { bilgilendirici } \\
\text { metin yazma }\end{array}$ & $\begin{array}{l}\text { T.8.4.2. Bilgilendirici metin yazar } \\
\text { T.8.4.14. Araştırmalarının } \\
\text { sonuçlarını yazılı olarak sunar }\end{array}$ \\
\hline
\end{tabular}

Tablo 2' den anlaşıldığı gibi “Vatandaşlık" adlı sekizinci temada beş farklı türde yazma etkinliği yer almaktadır. Bu etkinlikler beş farklı kazanımla ilişkilidir.

8. sınıf Türkçe (Millî Eğitim Bakanlığı) ders kitabında yer alan yazı türlerinin dağılımı dikkate alındığında etkinliklerde bilgilendirici metin oluşturmaya ağırlık verildiği görülmektedir. Daha sonra hikâye edici metinlere, en az sayıda da şiir yazma etkinliğine yer verilmiştir. Zengin şiir 
kültür mirasına sahip milletin nesilleri için hazırlanan kitapta şiir türüne biraz daha yer verilip bu alan üzerinde gelişme göstermelerini beklemek yanlış olmayacaktır. Zira şiir, sanatta estetik ve incelik isteyen bir türdür. Günümüz toplumunun ihtiyaç duyduğu incelik ve nezaketin, derslerde bu çalışmalarla çocukların bilinçaltına işlenerek tesis edilmesi mümkündür. Ayrıca çocuklarda edebî zevk oluşturabilmek için de şiir etkinliklerine biraz daha ağırlık verilmesi gerektiği değerlendirilmektedir. Çünkü şiir, edebî niteliğinin yanı sıra düz yazı türlerine göre daha özlü bir anlatıma sahiptir.

8. sınıf ders kitabındaki yazma etkinliklerinin ilgili metinle konu ve tür olarak benzerliğinin olması, metnin örnek alınarak öğrenci tarafından yazısını oluşturması açısından kolaylık taşımakta ve güzel bir seçim olarak dikkat çekmektedir. Bu, aynı zamanda metin ve etkinlik arasında tutarlılığ 1 da sağlamaktadır. Kitapta bu hususa genel olarak dikkat edilmişse de "Millî Kültür" temasının "Göç Destanı" metninde yazma etkinliği olarak Nasreddin Hoca ile ilgili bir etkinliğe yer verilmesi ve çalışmada mizahî ögelere yer verilmesinin istenmesi "T.8.4.8. Yazılarında mizahi ögeler kullanır." kazanımına kitapta yer verebilmek adına yanlış yapılmış bir seçimdir. Bu kazanımın farklı bir metinde tutarlılığı bozmayacak biçimde başka bir metnin etkinliği olarak öğrenciye kazandırılmaya çalışılabileceği düşünülmektedir.

Kitaptaki metinlerin yazma etkinlikleri, son etkinlikler olarak yer almaktadır. Programda yer alan kazanımlar dikkate alındığında "T.8.4.18. Cümlenin ögelerini ayırt eder, T.8.4.19. Cümle türlerini tanır, T.8.4.20. Fiillerin çatı özelliklerinin anlama olan katkısını kavrar." kazanımları da yazma becerisine ilişkin kazanım olarak geçtiğinden kitapta son kısımda yer almış ve yazma becerisine yönelik bir etkinlik gibi sunulmuştur. Ancak bu etkinliklerin "dil bilgisi” başlı̆̆ altında yer alıp değerlendirilmesi daha isabetli olacaktır. Zira öğrencilerin, tespit ettikleri bir ögenin altını çizmelerini yazma becerisi gerektirecek bir özellik olarak görmek doğru değildir.

Tablo 32. Sınıf Düzeylerine Göre Etkinlik ve İlişkili Olduğu Kazanım Sayısı

\begin{tabular}{lccc}
\hline Sınıf Düzeyi & Etkinlik Sayısı & $\begin{array}{c}\text { Sınıf Düzeyinde } \\
\text { Yazma Kazanımı } \\
\text { Sayısı }\end{array}$ & $\begin{array}{c}\text { Etkinliklerle } \\
\text { Ilişkilendirilmeyen } \\
\text { Kazanım Sayısı }\end{array}$ \\
\hline 5. Sınıf & 32 & 16 & 5 \\
\hline 6. Sınıf & 37 & 14 & 7 \\
\hline 7. Sınıf & 41 & 17 & 3 \\
\hline 8. Sınıf & 39 & 20 & 3 \\
\hline
\end{tabular}

Etkinlik ve kazanım tasnifinde genel anlamda Tablo.32'deki sonuç ortaya çıkmaktadır. Bu sonuçla 5. sinıf düzeyinde 5, 6. sınıf düzeyinde 7, 7. sınıf düzeyinde 3, 8. sinıf düzeyinde 3 olmak üzere toplam 18 kazanım yazma etkinlikleri içerisinde yer almamıştır. Bu durumun detayları incelendiğinde birçoğunun dil bilgisi kazanımı olduğu ve farklı etkinlikler içerisinde kazandırılmaya çalışıldığı belirlenmiştir. Dil bilgisi öğretimini amaçlayan ve kural-konu ediniminin ölçülmeye çalışıldığı etkinliklerin yazma becerisinin gelişiminde değerlendirilemeyeceği açıtır. Ancak öğretim programında "yazma" becerisi altında ele alındığı için bu kazanımlar içerisinde yer verilmiştir. 


\section{TARTIŞMA, SONUÇ VE ÖNERILER}

Türkçe ders kitapları hem içerik olarak edebî ürünler barındırmakta hem de dil becerilerinin gelişimi için etkinliklerle öğrencilerin beceri edinimini esas almaktadır. Çerçi (2016) ders kitaplarının anlama-anlatma sürecinin, öğretmen-öğrenci etkileşimi ile sürdürülmesi gerektiğini ortaya koymuştur. Hâl böyleyken alanyazındaki birçok çalışma Türkçe ders kitaplarında yer alan etkinliklerin yetersizliğini ortaya koymaktadır. (İşcan, 2004; Yılmaz, 2005; Duran, 2006; Kayabekir, 2010; Ayhan, 2010; Batur, 2010; Kırbaş, Orhan ve Topal, 2012; Akın, 2015; Mazlum ve Mazlum, 2016; İşcan ve Cımbız, 2018). Bu açıdan bakıldığında dil becerilerinin ve yazma becerisinin öğrencilere kazandırılması için kullanılan temel kaynak olan ders kitaplarının incelenmesi ve gerekli düzenlemelerin gerçekleştirilmesi oldukça önemlidir.

Yazma sürecinin özendirilmesi, teşvik edilmesi ve geliştirilmesinde yazma etkinlikleri büyük önem taşımaktadır. Wiener (1990), öğretmenin bu süreci doğru planlayıp öğrencilere aktarma aşamasında da bunu yansıtması gerektiğini ortaya koymuştur. Fusco ve Noren (1988) ise yazma becerisinin gelişiminde kullanılan resimli kitapların aynı zamanda hikaye kavramını anlama, ayrıntıları tanıma, sıralama ve karakter gelişimi gibi temel bilişsel ve dilbilimsel becerilerin gelişimini de destekleyebileceğini tespit etmiştir. McGee ve Tompkins (1983) dil becerilerinin gelişiminde kullanılan görsel içerikli kitapların öğrencilerin doğal dil yeterliliklerinden yararlandığını ve buna bağlı olarak okuma becerilerini geliştirmekle kalmayıp aynı zamanda onların hayal güçlerini ve yazma stillerini ve ifade tarzı duyarlılıklarını da geliştireceğini ortaya koymuştur. Ramies'e (1983) göre yazma eğitimi; yazılı ürün üzerinde yoğunlaşmaktan, süreç yazımına vurgu yapmaya başlamıştır. Bu da doğru dil modellerini taklit etmeye, kopyalamaya ve dönüştürmeye odaklanan bir öğrenme sürecinin sonunda öğrencilerin neler yapabileceğine vurgu yapar. Daha sonra yazmayı planlama, yazma, gözden geçirme ve düzenleme gerektiren bir süreç olarak görür (Hedge, 2000; Ramies, 1983). Türkçe ders kitaplarındaki yazma etkinliklerinin de süreç temelli olarak planlanması, bu aşamalarla düzenlenmesi daha etkili bir edinim sağlayacaktır. Yibre'ye (2019) göre ders kitabı geliştiricilerinin, öğrencileri işbirlikçi yazma pratiği yapmak için kolayca fikir üretmeleri için motive edebilecek ikili/grup çalışması yazma etkinlikleri üretmesi gerektiğini ifade etmektedir. Arıcı (2008) üniversite öğrencilerine yönelik yaptığı çalışmada yazılı anlatım çalışmalarına ilgi duyan öğrencilere rehberlik yapılarak düzenli çalışma ortamı sağlanabileceğini ortaya koymuştur.

Yabancı araştırmalar kadar Türkçe nezdinde yapılan çalışmalar da yazma becerisinin gelişiminde süreç odaklı yaklaşımın etkililiğini ortaya koymaktadır. Demir Atalay (2015) incelediği ders kitabında; yazma süreçleri açısından yazma öncesi, sırası ve sonrası etkinliklerinin yetersiz olduğunu tespit etmiştir. Araştırmamızın bulguları da bunu desteklemekte ve Türkçe ders kitaplarındaki yazma etkinliklerinin daha çok ürün odaklı ve öğretmen yönlendirmesiyle ilerleyecek şekilde planlandığı görülmektedir. Arıcı ve Ungan'a göre (2015) yazılı anlatım becerisi, uygulamalarla geliştirilecek bir beceri olduğundan Türkçe derslerinde öğrencilerin bu yeteneklerini geliştirici ve öğrencilerin yazmaktan hoşlanacakları nitelikte yazılı anlatım çalışmaları yaptırılması gerektiği ortaya konulmuştur.

2020-2021 eğitim-öğretim yılında kullanılan 5. Sınıf Türkçe Ders Kitabı (Anıttepe Yayıncılık), 6. Sınıf Türkçe Ders Kitabı (Ekoyay Eğitim Yayıncılık), 7. Sınıf Türkçe Ders Kitabı (Özgün Matbaacılık) ve 8. Sınıf Türkçe Ders Kitabı (Millî Eğitim Bakanlığı) yazma etkinliklerinin incelenmesiyle elde edilen bulgular değerlendirilmiştir. Bu bulgular ışığında ulaşılan sonuçlar ve bunlara bağlı öneriler şöyledir: 
- Türkçe ders kitapları içerisinde farklı metin türlerine ait yazma etkinlikleri yer almaktadır.

- Yazma etkinlikleri hazırlanırken Türkçe Öğretim Programı́nda (MEB, 2019) yer alan kazanımlar dikkate alınmıştır. Bulgularda en fazla/en az yer verilen kazanımlar tespit edilmiştir. Öğrencilerin yazma becerisinde yetkinlik kazanması için tüm kazanımlara eşit şekilde yer verilmelidir.

- Türkçe ders kitaplarındaki etkinlik yönergeleri incelendiğinde birçok etkinlikte birden fazla kazanımın yer aldığı, birden fazla becerinin kazandırılmaya çalışıldığ görülmüştür. Bulgular ışığında 8. sınıf Türkçe ders kitabının nispeten yeterli düzeyde olduğu; 5, 6, 7. sınıf kitaplarının ise yazma becerisinin gelişimi için tam anlamıyla yeterli olmadığı değerlendirilmektedir.

- Ders kitaplarının daha nitelikli, kendi içerisinde aşamalı bir gelişim gösteren etkinliklerle tasarlanması gerekliliği ortaya konulmuştur.

- Yazma becerisinin ölçülmesine ve değerlendirilmesine yönelik değerlendirme formu, akran değerlendirme formu, öz değerlendirme formu gibi formların her temada yer alması gerekmektedir.

- Kitapların yazımında görev alan akademisyen, uzman ve öğretmenlerin öğrencilerin yaş, gelişim gibi temel özelliklerinin yanı sıra hem değerler eğitimini hem de öğrencilerin duygusal, bilişsel, duyusal, psiko-sosyal gelişim süreçlerini dikkate almaları gerekmektedir.

- Yazma etkinlikleri içerisinde istenecek/yazdırılacak metin türleri belirlenirken öğrencilerin sınıf düzeyleri dikkate alınmalıdır. Etkinlikler için ayrılan çok uzun sayfalar/bölümler öğrenciler tarafından fazla bulunabilmekte ve göz korkutucu bir hüviyet taşımaktadır. Bunların daha makul, öğrenciler tarafından müspet karşılanacak uzunlukta olması daha doğru olacaktır.

- Yazma etkinliklerinin ürün odaklı değil süreç odaklı olarak planlanması ve öğretmenin rehberliğinde bu sürecin etkin bir şekilde yürütülmesi gerekmektedir. Halihazırda öğretmen kılavuz kitaplarının kullanılmadığı öğretim programları uygulamada olduğu için öğretmenin bu süreci yönlendirmesi çok büyük önem taşımaktadır.

- Öğrencilerin yaş ve gelişim düzeyi dikkate alınarak öyküleyici metinlere daha fazla yer verilmesinin yerinde olacağı değerlendirilmektedir. Ayrıca duyguların dişavurumuna da katkı sağlayan ve edebî açıdan daha nitelikli içerikler sunan şiir yazma etkinliklerinin arttırılması da yerinde olacaktır.

- Türkçe dersinin dışında Seçmeli Yazma Becerileri dersine yönelik de öğretim programı doğrultusunda yazılı anlatım çalışmaları/materyalleri hazırlanmalıdır.

Gelişen şartların, değişen teknolojinin ve küçülen dünyanın gelecek nesiller tarafından daha iyi anlatılması yazma becerisi gelişmiş öğrencilerle mümkün olacaktır. Yazı yazma süreci öğrencilere bir zorunluluk, görev, ödev kapsamında değil; kişisel gelişimlerini ve kendilerini ifade etmelerine yönelik beceri edinmelerini sağlayıcı şekilde aktarılmalıdır. Yazıyı, yaşama bir bakış ve kendini doğru ifade etme süreci olarak benimseyen öğrencilerin severek, isteyerek yazacakları; aynı zamanda bu becerinin gelişimi için daha fazla çaba gösterecekleri değerlendirilmektedir. 


\section{KAYNAKÇA}

Aktaş, Ş. ve Gündüz, O. (2004). Yazılı ve sözlü anlatım-kompozisyon sanatı. Ankara: Akçă̆.

Akın, E. (2015). Türkçe çalışma kitaplarındaki (6, 7 ve 8. Sınıflar) dil bilgisi etkinliklerinin çeşitli açılardan değerlendirilmesi. International Periodical For The Languages, Literature And History Of Turkish Or Turkic, 10(15), 19-34.

Arıcı, A. F. (2008). Üniversite öğrencilerinin yazılı anlatım hataları. Uludağ Üniversitesi Eğitim Fakültesi Dergisi, 21(2), 209-220.

Arıcı, A. F. ve Ungan, S. (2015). İlköğretim ikinci kademe öğrencilerinin yazılı anlatım çalışmalarının bazı yönlerden değerlendirilmesi. Dumlupınar Üniversitesi Sosyal Bilimler Dergisi, (20), 317-327.

Ayhan, Y. (2010). İlköğretim 5. Sınıf Türkçe ders kitabı resimlemelerinin biçim ve içerik açısından 11 yaş grubuna uygunluğu ve ayn yaş grubu öğrencilerin yaptığı resimlemelerle karşılaştırılması. Yayımlanmamış yüksek lisans tezi, Gazi Üniversitesi, Eğitim Bilimleri Enstitüsü, Ankara.

Başkale, H. (2016). Nitel araştırmalarda geçerlik, güvenirlik ve örneklem büyüklügünün belirlenmesi. DEUHFED, 9(1), 23-28.

Batur, Z. (2010). Anadili öğretiminde gösterge bilimin yeri: ana dili ders kitaplarındaki sözel metinlerle gösterge metinleri bütünselliğinin analizi. Turkish Studies, 5(4), 174-200.

Belet Boyacı, Ş. D., Güner, M. ve Babadağ, G. (2017). “Dünyada Başka Şekilde Yaşamak da Mümkün mü?" değer eğitiminde "Küçük Kara Balık" örneği. Eğitimde Nitel Araştırmalar Dergisi, 5(3), 172-194.

Çapraz-Baran Ş. ve Diren, E. (2019). Ortaokul ve imam hatip ortaokulu Türkçe 5. sınıf ders kitabı. Ankara: Anittepe Yayıncilik.

Çerçi, A. (2016). 6. sınıf Türkçe dersi öğrenci çalışma kitabının etkinliği oluşturan unsurlar bakımından değerlendirilmesi. Uluslararası Türkçe Edebiyat Kültür Eğitim Dergisi, 5(4), 1984-1998.

Demir Atalay, T. (2015). Yazma becerisi açısından örnek bir kitap incelemesi. AÜ Türkiyat Araştırmaları Enstitüsü Dergisi [TAED], (54), 727-777.

Demirel, Ö. ve Kıroğlu K.(2005). Konu alanı ders kitabı incelemesi. Ankara: PegemA Yayınları.

Demirel, T. (2019). Ortaokul ve imam hatip ortaokulu Türkçe 6. sınıf ders kitabı. Ankara: Ekoyay Eğitim Yayıncılık.

Duran, S. (2006). Türkçe derslerinde resimlerin kullanımı ve öğrencilerin metinleri anlamalarına etkisi. Yayımlanmamış yüksek lisans tezi, Marmara Üniversitesi, Eğitim Bilimleri Enstitüsü, İstanbul.

Durdu, L. ve Özden, Y. (2016). Eğitimde üretim tabanlı çalışmalar için nitel araştırma yöntemleri. Ankara: Anı Yayıncılık. 
Erkal, H. ve Erkal, M. (2019). Ortaokul ve imam hatip ortaokulu Türkçe 7. sınıf ders kitabı. Ankara: Özgün Yayıncılık.

Eselioğlu, H., Set, S. ve Yücel, A. (2019). Ortaokul ve imam hatip ortaokulu Türkçe ders kitabı 8. Ankara: Millı̂ Eğitim Bakanlığı.

Fusco, E. ve Noren, C. (1988). Wordless books: An early language development program. Littleton, MA: Sundance Publishers \& Distributors, Inc.

Göçer, A.(2014). Yazma eğitimi. Ankara: Pegem Akademi

Gögüş, B. (1978). Orta dereceli okullarımızda Türkçe ve yazın eğitimi. Ankara: Kadığlu Matbaası.

Hedge, T. (2000). Teaching and learning in the language classroom. Oxford: Oxford University Press.

İşcan, A. (2004). Illköğretim ikinci kademe sekizinci sınıf Türkçe ders kitaplarındaki metinlerin öğrencilere estetik zevk kazandırmadaki rolü. Yayımlanmamış yüksek lisans tezi, Atatürk Üniversitesi, Sosyal Bilimler Enstitüsü, Erzurum.

İşcan, A. ve Cımbız, A. T. (2018). Ortaokul 5. sınıf Türkçe ders kitabındaki resimlerin metinlerle uyum düzeyinin incelenmesi. Abant İzzet Baysal Üniversitesi Ĕ̆itim Fakültesi Dergisi, 18(1), 250272.

Kayabekir, T. (2010). İlköğretim 8. Sinıf Türkçe ders kitabı tasarımında yer alan illüstrasyonların (resimlemelerin) metne uygunluk açısından değerlendirilmesi. Yayımlanmamış yüksek lisans tezi, Gazi Üniversitesi Eğitim Bilimleri Enstitüsü, Ankara.

Kırbaş, T., Orhan, S. ve Topal, Y. (2012) İlköğretim Türkçe ders kitaplarındaki görsel ögelere öğretmen görüşlerinden hareketle eleştirel bir bakış. Turkish Studies, 7(4), 2225- 2235.

Mazlum, Ö. ve Mazlum, F.S. (2016). İlköğretim 4. Sınıf ders kitaplarının görsel tasarımına yönelik öğretmen görüşlerinin değerlendirilmesi. Sanat Ĕ̆itimi Dergisi, 4(1), 1-18.

Oğuzkan, F.(1993). Eğitim terim sözlüğ̈̈̈. Ankara: Emel Matbaacılık.

MEB (2006). Türkçe dersi öğretim programı (ilkokul ve ortaokul 1, 2, 3, 4, 5, 6, 7 ve 8. sinıflar). Ankara. Millî Eğitim Bakanlı̆̆1

MEB (2019). Türkçe dersi öğretim programı (ilkokul ve ortaokul 1, 2, 3, 4, 5, 6, 7 ve 8. sinıflar). Ankara: Millî Eğitim Bakanlığ1

McGee, L. ve Thompkins, G. (1983). Wordless picture books are for older readers. Journal of Reading, 27(2), 120-123.

Özbay, M. (2006). Türkçe özel öğretim yöntemleri II. Ankara: Öncü Kitap ve Yayıncıllk.

Özdemir, E. (1991). Türk dili ve edebiyatı öğretimi. Eskişehir: Anadolu Üniversitesi Açıköğretim Fakültesi Yayınları.

Ramies, A. (1983). Techniques in teaching writing. Oxford: Oxford University Press.

Sever, S. (2004). Türkçe öğretimi ve tam öğrenme. Ankara: Anı Yayıncılık.

TDK (2011). Türkçe sözlük. Ankara: Türk Dil Kurumu Yayınları.

Yangın, B. (2002). Kuramdan uygulamaya Türkçe öğretimi. Ankara: Dersal Yayıncllık. 
Şimşek, H. ve Yıldırım, A. (2011). Sosyal bilimlerde nitel araştırma yöntemleri. Ankara: Seçkin Yayıncilik.

Y1lmaz, A. (2005). İlköğretim okullarn ilk kademede okutulan ders kitaplarının resimlemeleri yönünden değerlendirilmesi. Yayımlanmamış yüksek lisans tezi, Anadolu Üniversitesi, Eğitim Bilimleri Enstitüsü, Eskişehir.

Yibre, M. (2019). An analysis of the structure of group writing activities in English textbook. International journal of education and literacy studies, 7(2), 122-133.

Wiener, H. S. (1990). Any child can write. New York: Bantam Books. 